\title{
Corporate Governance and Technological Capability Development: Three Case Studies in the Chinese Auto Industry ${ }^{1}$
}

\author{
Industry and Innovation, 16 (4), September 2009, pp.525-544. \\ JIAJIA LIU* \& ANDREW TYLECOTE** \\ *Management School, University of Sheffield, Sheffield, UK, \\ ** Management School, University of Sheffield, Sheffield, UK
}

\begin{abstract}
This paper examines how firms' technological capability development is affected by corporate governance, broadly understood: 'how and by whom the firm is directed and controlled'. Three state-owned companies are studied. Shanghai Auto Industry Corporation is a long-established 'favoured' enterprise controlled on rather traditional lines. Chery is a small under-funded latecomer that receives exceptional 'engagement' from its controlling local and provincial government. Guizhou Tyre is long-established but also receives exceptional engagement. The firms' governance structures and their processes of technological capability-building were tracked and compared. Data on SAIC and Chery was mainly from secondary sources; on GTC, from extensive interviewing of management and site observations. There were two main findings: first, it was the two with unusual engagement which were more successful in developing 'endogenous' or 'self-reliant' technological capability. Second, two alternative technological strategies could be distinguished: 'bundled' or 'unbundled' technology acquisition. Chery and GTC chose 'unbundling'. We show why it was more successful and why it followed from the corporate governance situation.
\end{abstract}

KEY WORDS: Technological capability, corporate governance, China, automotive industry

\section{Introduction}

The rapid growth of the Chinese economy has not been matched by the development of 'indigenous' or 'independent' technological capability by Chinese firms. That has been, at best, patchy. As Gu puts it (2003, p.14): 'China as a whole has not moved to the stage of being able to create distinctively specialised competitiveness in the international market beyond labour-intensive manufactures'. Indeed, even on the national market, Chinese firms in medium and hightechnology industries have in general remained dependent on technology transferred from abroad. The automobile industry - which in the OECD classification is a medium-high-technology sector - is an appropriate sector to consider when seeking an understanding of this Chinese failure, or limited success. It is, after all, one of the priority sectors chosen by the Chinese government for development. The privileging of private cars in Chinese transport policy - with its inevitable downside in terms of congestion, pollution and dependence on foreign oil suppliers - can only be explained and justified in terms of the government's determination to build a strong Chinese car industry.

\footnotetext{
${ }^{1}$ This paper is output of an ESRC funded project: 'Corporate Governance and Technological Development of China'. Project number: RES-000-221504.
} 
The last decade has indeed seen the Chinese automobile industry surge - sales have grown $40-60 \%$ p.a. It has emerged as an "engine" of the Chinese economy, providing a huge number of jobs, spillovers into the wider economy, and contributing to regional economic development. While achieving substantial success in terms of content localization and capacity building, it has been weak in developing its own technological capabilities and remains, or remained until the last year or two, almost completely reliant on foreign joint venture partners for advanced automotive technologies (Gallagher, 2003; Lu \& Feng, 2004).

Lu and Feng (2004) offered two main reasons for the unsuccessful story. First of all, flawed industrial policy failed to foster capability development and innovation. In order to consolidate the highly fragmented industry to build a group of globally competitive large, multi-plant corporations, the 1994 Automobile Industrial Policy set up entry barriers such as stringent assets and capacity requirements for start-up companies; investment was only officially encouraged in three large-scale companies, called the "Big Three". Such favouritism curbed domestic competition and hence firms' incentive to develop endogenous technological competitiveness. Second, while the industry relied passively on technology spillovers when joint-venturing with foreign companies, little knowledge was gained along with production capacity. The foreign companies essentially selected what would be transferred and how, without necessarily teaching their Chinese partners anything significant.

A growing body of literature (Lee et al., 1996; Harwitt, 2001; Wang, 2001; Jin, 2004 and Lu \& Feng, 2004) criticizes large-scale Chinese enterprises as lacking the incentive and ability to develop 'self-proprietary' cars - cars whose intellectual property they own and whose technology they have mastered - despite explicit and substantial financial and policy privileges. However a few smaller-scale late-comers are doing significantly better - e.g. Geely and Chery. The former gained orders for over 100,000 self-branded cars to 100 countries at the 2005 Frankfurt Auto Show, making it envied by the well-bred "big brothers". Chery, after pioneering joint ventures overseas in 2003, launched China's first passenger car engine with full intellectual property in 2006. 5,000 such engines were sold to USA in the same year. In 2008, Chery also became the first Chinese automaker to develop the first low emission Dual Overhead Cam (DOHC) engine with its own intellectual property right in China (http://www.chery.cn). In this context, it is pertinent to raise the following question: why has the performance of enterprises varied so much under similar market conditions?

The main aim of this paper is to show how existing theories of the effects of corporate governance on technological capability can be adapted to extend our understanding of the above. Tylecote and Cai (2004) showed how the governance flaws of Chinese state-owned enterprises (SOEs) can affect technological development. Their arguments help in understanding the failings of the 'Big Three' car companies. But one of the rather successful 'latecomers', Chery, is a state-owned enterprise too. We need to explain success as well as failure among SOEs in developing technological capability. In Section 2 we explain how corporate governance can vary among Chinese SOEs in ways which can be expected to affect technological development. In Section 3 we describe case studies of three state-owned enterprises in the motor industry which exemplify just such corporate governance variations as we expect to be significant. Shanghai Auto Industry Corporation (SAIC), Chery, and Guizhou Tyre Co.Ltd (GTC) are studied: the first two mainly from published sources, the third mainly on the basis of semi-structured interviews with senior and middle managers during June 2006. Analysis is made both longitudinally (how changes take place within the organisation) and laterally (how behaviour varies between two different companies). A combination of archive search, site observations and cascade interviews was employed in the GTC case study. In-depth semi-structured questions were put to 5 interviewees - the chief executive, the party secretary/ chief operations officer, the chief engineer, one line manager and one of shop-floor workers - to find out the evolution of the firm's technological capability and corporate governance. Section 4 discusses major findings and makes suggestions on future work. 


\section{Corporate Governance in China and its Effect on Technological Development}

Corporate governance is a multi-faceted subject. Understood broadly, it is the set of processes, customs, policies, laws and institutions affecting the way in which a corporation is directed, administered or controlled (Tylecote, 1999; OECD, 2004). The most-researched domain in corporate governance is the "agency" problem. The principal-agent relationship is defined as a contract under which principals employ the agent to perform on their behalf, which involves delegating some decision-making authority to the agent (Jensen and Meckling, 1976). Due to information asymmetry, opportunism and bounded rationality, the agent will not always act in the best interest of the principal. In China, the traditional principal-agent issues are particularly profound in state enterprises, manifesting themselves in two layers (Tylecote \& Cai, 2004):

- Agents being accountable to agents. In China by definition the ownership and residual claim rights of SOEs belongs to all - hence in essence to no-one. From the external governance point of view, government officials are in charge of the firm; firm managers answer to them. However, these officials too perceive themselves as agents, not principals; agents not of the people, but of the senior officials who appointed them. The agency problem is thus multiplied, or rather squared (or cubed).

- Managers' career paths as officials. Anyone familiar with the Chinese political system and industrial structure can confidently list the one-to-one matches between SOE managers' positions at different levels with those of government officials. Thus CEOs of local firms are paid as section chiefs (Chuji Daiyu) or director generals (Juji Daiyu) whereas CEOs of "Central Enterprises" (Zhongyang Qiye) are normally regarded as vice ministers (Fubuzhangji Daiyu). Their quasi-official status largely shapes the mentality of SOE managers. They are usually picked by officials, and may be officials themselves already; anyway, they often end up as an official of a higher position after staying in the firm for a forecastable period of time (normally around 5 years). This makes the agency problem more acute, because it is inherently linked to term and time horizon. Given a long enough time in post, it is rather easy for an agent's performance to be evaluated reliably and accurately: shrewd investments pay off in the end, while unwise economies in the building of capability and the nurturing of customers, come back to haunt the myopic manager responsible. An agent who expects to be elsewhere soon, must care more about superficial impressions than longterm consequences.

How do these flaws of corporate governance affect firms' technological capabilities? Before going further, the meanings of several terms used in this paper need to be clarified. First, in this research technological capability is defined as a process of acquiring technical knowledge or a process of organizational learning (Rosenberg and Frischtak, 1985). The concept of technical knowledge here is distinct from that of accumulated experiences or tacit "know-how", which can be gained automatically through day-to-day operations and survival - the former requires explicitly devised effort and investment (Bell, 1984; the italics are ours). Hence the approach to technological capabilities always involves active learning and most importantly, cost and risk. In turn, a firm's technological capability development depends on how well its corporate governance system copes with the following three challenges (Tylecote \& Conesa, 1999):

- Visibility - capability-building activities within the firm may be low in visibility to outsiders (such as shareholders or monitoring officials); to the extent that they are, they cannot be properly monitored without close engagement.

- Novelty - to the extent that technologies and the markets in which they are to be exploited are novel, 
capability-building activities cannot be properly monitored without industrial expertise. (This challenge has been subdivided into 'need for reconfiguration' and 'technological opportunity' in Tylecote and Visintin, 2008, but the need for industrial expertise emerges just the same.)

- Stakeholder spill-overs - if technological learning requires substantial inputs from, and/or offers gains to, employees and/or related firms, these stakeholders need to be in some important sense included in governance - that is, they should have power or influence, or at least their interests ought to be taken into account.

Following this thread, the handicaps of the governance mechanism of Chinese SOEs for technological capability naturally emerge. First, as mentioned above, the engagement level of firm controllers is generally low and relationship between most SOEs and their supervising officials is mostly arms-length. Although in general managers maintain good connections (guanxi) with bureaucrats, this is usually done for easier access to cheap finance or insider intelligence about potential policy adjustments. Few would expect to see government officials going out of their way to monitor firms, let alone to understand and oversee their process of technology acquisition, and they also lack the industrial expertise to do this. Second, the key relationships which the managers need to cultivate are with senior officials. Their emphasis on this limits their attention to relationships with employees and related firms which are key for inclusion.

Central government's drive to enhance technological competitiveness has (it must be conceded) put pressure on officials to worry about technological capabilities of firms they are in charge of. Lacking engagement and expertise, however, they are most easily satisfied by developments with high visibility and rapid effects. From this point of view the ideal means of (apparent) technology development is to acquire a single bundle of technologies. The concept of bundling is familiar in product markets - selling two products together (Nalebuff, 2004). In technology markets it goes back at least to Arora (1996), who argues that the notorious problems of selling tacit knowledge, or knowhow, can be avoided, or limited, by bundling complementary inputs with know-how in a technology package, making the contract more enforceable. This is seen from the point of view of the seller in a developed country. We consider technology bundling from the point of view of the buyer in a developing country.

What then is a technology bundle for a developing country firm? An assembled product such as a car of course contains a multitude of components. Each is produced using certain process and product technologies. A number of components are combined into sub-systems (brakes, engines, etc.) which themselves require further process and product technologies, as does the final assembly into the finished product - the car. Many of the process and product technologies will be covered by patents or other forms of intellectual property protection which will be infringed unless licenses are granted. The successful adoption of the technologies will require blueprints for production methods, and training. The process technologies are largely embodied in more-or-less specific equipment. A full technology bundle will then contain the blueprints, licenses, training and equipment required for all the components, sub-systems and systems. (The classic form of providing at least the equipment is the 'turnkey' plant, in which the provider takes responsibility even for putting the equipment together on site.) It may well be, however, that the firm buying the bundle is not to produce all the components and sub-systems in-house. Some may be withheld from the bundle, either because the buyer is held not capable of handling the technology, or because it is regarded as unsafe from the seller's point of view to disclose key technologies. The components withheld are then to be bought, on a continuing basis, either from the seller or from suppliers chosen by it.

The advantage from the seller's point of view is clear, and is essentially as argued by Arora: the seller keeps control. The main advantage from the buyer's point of view is speed and simplicity: there is one bundle, one deal, one provider who (presumably) knows how everything fits together and can quickly make sure it all works, as long as local 
conditions do not get in the way. (A further advantage is the obverse of the advantage to the seller: there will be more willing sellers because they have less fear of losing control.) It can easily be seen that the speed and simplicity of a bundle are of particular value for the typical Chinese SOE top manager. He can quickly show his 'disengaged' monitoring officials, results, in terms of technology: new products, new equipment, new processes. The new products will presumably show quick results too in terms of market share. The bundle is likely also to deliver quick profits: the main up-front payment will be for equipment, and that shows in the accounts as an asset not as a current cost to be subtracted from profits. Of course, large amounts of money will need to be raised - which has normally meant borrowed from banks - and interest paid on that. However, state-owned enterprises, particularly large ones owned and favoured by central government, have long been able to borrow very cheaply indeed.

Consider, on the other hand, what may be gained by a large measure of unbundling. Unbundling can be defined as acquiring the capability to produce each component and sub-system, and system, separately, and indeed at the extreme will involve separate acquisition of each element (machinery from one supplier, training from another, blueprints from a third). It is easily apparent that not every part of a car (or any other assembled product) is equally difficult to make. Some parts can be copied (legally or illegally) by a little reverse engineering. Others may require a modest amount of in-house R\&D by the Chinese firm, or perhaps by a domestic supplier working to its specification. Not all the equipment need be bought, new, from foreign suppliers. Some may be available, used, on the market. Other equipment may be available to an adequate standard from a domestic supplier. Even where components and sub-systems do require technology from foreign sources, it is likely that the simpler the component (and element), the larger the number of potential providers, and thus the better the Chinese firm's bargaining position. Another gain arises from the process of decomposition itself. Someone (or some team) in the Chinese firm has to work out how all the parts and elements, literally and metaphorically, fit together. To use the fashionable term, they have to master systems integration. That capability gives them the strategic ability to plan how they will develop new models with ever more in-house and in-country inputs, physically and technologically.

The disadvantages of unbundling are clear. It introduces a multitude of uncertainties: any one component may turn out to be unfit for purpose in itself. Or it may be mismatched with its neighbours in the assembly process: systems integration is difficult. The result will be a multitude of teething troubles. These will have to be worked through with the help of suppliers, customers and shop-floor workers, and this will take time. It is clear too that the corporate governance system of the typical Chinese SOE must magnify all these disadvantages. The top manager does not have much time to show results to dis-engaged monitoring officials. They will easily appreciate the result of the teething troubles - delays in product launch, poor initial reception by customers, slow build-up of production. They will not have time or patience to go round the factory having it explained to them how a second-hand machine here, a little bit of shop-floor ingenuity there, some discreet reverse engineering somewhere else, have each taken a per cent or two off production costs; still less, how the firm is learning to do better next time. Further, we pointed out above that the SOE manager needs to cultivate relationships with monitoring officials, and with other senior officials whose support may be helpful and whose hostility could be damaging. This leaves less time, and commitment, for the relationships key to inclusion - with employees and related firms - on which the firm will depend, to make unbundling work.

\section{Case Studies - Chery and SAIC}

In this section, we will put our arguments in the context of the Chinese auto industry through case studies of two state- 
owned car assembling firms. Since capabilities are processes embedded in firms, we assume an organizational and empirical lens, rather than an economic and formal modeling one (Barney, 1991; Peteraf, 1993). In particular, we observe how both companies' technological capabilities evolve over time; their different approaches to capability building are compared and analysed in relation to their governance mechanisms. Technological capabilities of both firms are assessed in terms of their ability to: i) identify technological needs and to select the technology to fulfil the need; ii) assimilate, maintain, modify and improve the selected technology; and iii) promote technological learning (Kumar et al., 1999; Lall, 2001).

\subsection{Snapshots and Features of Corporate Governance}

\section{SAIC}

Shanghai Automotive Industry Corporation (Group) has a history that can be traced back till World War II. After the war, a Kuomintang magnate purchased Shanghai Car Plant from an English company to repair and assemble Chevrolet and Austin series. In December 1955 Shanghai Car Plant was communised and renamed as "Shanghai Internal Combustion and Components Company" and was conglomerated and renamed again in 1996 as "Shanghai Automotive Industry Corporation (Group)". Together with First Auto Works (FAW) and Dongfeng Motor Corporation (DMC), SAIC is known as one of the favoured 'Big Three' and the largest on production capacity and market share (http://www.saicgroup.com). In year 2004, the $\$ 11.7$ billion main business revenue brings it to the "Fortune 500 " list as one of few Chinese firms. SAIC's ownership entirely belongs to Shanghai State-owned Assets Supervision and Administration Commission (the regional division of SASAC). Its main body is SAIC Motor Co., Ltd, which owns $50 \%$ of SAIC's two joint venture passenger car assemblers: Shanghai Volkswagen (SHVW) and Shanghai General Motor (SHGM). SAIC Motor also owns 70\% of its listed company - Shanghai Automotive Co., Ltd (SA) and in 2004 became the controlling shareholder (48.92\%) of Ssangyong, the fourth largest car company in South Korea. In 2004 it made 11 models of passenger cars. Apart from Saibao ${ }^{2}$, built by SA in its Yizheng plant since 2002, all other ten products are sold under the brand names of its foreign partners.

Since 1978 SAIC has been ruled by four different executives, and their service terms were 4, 8, 4 and 7 years respectively (the fourth chief was still in position in May, 2009.. Three out of the four were transferred from senior positions in Shanghai government and two remained officials after leaving SAIC ${ }^{3}$. Hu Maoyuan, the current CEO who was appointed in 1999, represents an exception. His career started in one of SAIC's factories and he has been in the management since 1986 (http://www.saicgroup.com). SAIC has always been well looked after by government officials at both levels. One example is that since 1985 SAIC was given the privilege to retain $\$ 1,250$ out of the profit from each Santana. By 2002 this reservoir had reached more than $\$ 50$ million. However, SAIC's R\&D expenditure is no more than $1 \%$ of its revenue (Jin, 2004).

\section{Chery}

Chery Automobile as a small-sized $\mathrm{SOE}^{4}$ was founded in 1997. It is located in Wuhu, a medium sized city in the landlocked province of Anhui. It has 8,500 employees and sold 185,000 passenger cars in 2005, a 118\% increase from 2004, of which all 4 models are branded with its own intellectual property (IP). With a market share of nearly $13 \%$, it ranks $7^{\text {th }}$ of 33 passenger car companies. Though small in size, short in history and simple in structure, Chery has

\footnotetext{
2 In 2005, Saibao ceased production due to sagging profit margin.

${ }^{3}$ The other one retired afterwards, yet he still is "senior consultant" both in SAIC and in Shanghai Auto Industry Development Committee.

${ }^{4}$ Its "claimed" start-up capital was $\$ 200$ million according to Lu and Feng (2004).
} 
caught the nation by surprise - it developed its first 2 models of cars in just 8 months, less than 2 years after its establishment; it is the first to export branded cars and the first to build cars with Chinese IP overseas ${ }^{5}$; in 2006, shortly after the launch of 4 new models and China's first full-IP passenger car engine, it has become the biggest car exporter based in China, with highest total sales growth (http://www.chery.cn).. According to the statistics of International Organization of Motor Vehicle Manufacturers, in 2006, Chery has become the world's fastest growing car manufacturer at the rate of $65.62 \%{ }^{6}$. In 2009 , Chery becomes the largest car manufacturer as well as exporter with Chinese brand names and IPR.

However, the creation of Chery was dramatic. The relatively remote city of Wuhu was a latecomer to the new economy. In desperate search of growth potential, the local officials were fascinated by the lucrative business of auto production. Despite the strict entry control by the central government, they decided to build their own car company. In 1998 they quietly skirted the regulations and recruited Yin Tongyao, a trained engineer, who had been a rising star in one of the joint ventures with VW. Yin became vice-president of Chery and has been in effective charge since then - a total of 9 years. Chery received whole-hearted support by Anhui and Wuhu government. National regulations forbade new entries, so the officials named the enterprise "automotive components" company. When Chery built its first car, VW was furious due to the apparent imitation, so was the central government (Hessler, 2005). But during the reform era, as authority has become decentralized there is a common strategy, push the boundaries first, and then ask forgiveness. For more than a year, Wuhu's officials negotiated with the central government, finally a compromise was made: by giving out $20 \%$ of its shares, Chery became affiliated to SAIC. In so doing it obtained the necessary licenses to manufacture cars and establish a sales network. However, SAIC in this deal pictured its role as lenient rather than strategic, it made clear in the memorandum that SAIC's relation with Chery does not involve investment, management, debt, or dividend. SAIC realised its mistake afterwards; however, their marriage stopped shortly after Chery won favour with high state officials, leaving settlement of the $20 \%$ share a rumour.

\subsection{Approaches to Technological Capabilities Development}

\section{SAIC}

The first half of SAIC's technological development history $(1978-2002)$ resembles that of most other Chinese car companies, that is, seeking technological spill-overs from international joint-venturing. SAIC used to have its own brand and product development capability back in the 1950s. After Russian technical support withdrew from China, "Phoenix" was built in Shanghai Auto Assembly Plant, the predecessor of SAIC. "Phoenix" later was renamed "Shanghai" and expanded into 4 different models and reached a capacity of 5,000 in $1975^{7}$. Since 1978, SAIC followed the government's urge to seek co-operation with foreign companies. In 1984 it started a joint venture with Volkswagen and in 1997 another with General Motor. The first type built in Shanghai VW was Santana. In 1991 SAIC decided to cease producing "Shanghai" and devote $90 \%$ of its retained profit from "Shanghai" to Santana project. The initial form of production in SHVW was CKD (complete knocked-down) assembly. WW's contribution mainly took the form of bundled product and production technologies - according to the contract, without VW's discretion SAIC cannot make adjustment to the original design ("not even a screw", Lu \& Feng, 2004). Although VW and SAIC shared equal investments in SHVW, the later was not happy to see disproportional profit distribution, especially after paying extra to

${ }^{5}$ In 2003 Chery signed a contract with Iran to build a plant there, assembling CKDs with Chery's brand name.

${ }^{6} \mathrm{http}: / /$ oica.net/wp-content/uploads/2007/07/chery.pdf

${ }^{7}$ There were only 70,000 cars built in China from 1958 to 1991 , and in 1982 total production was 5,101. 
imported parts. Significant effort was hence made to develop parts and components production capacity. In 1991 Santana became the first to be exempted from import licensing, symbolizing its realisation of localised production. However, after satisfactory profit margin - also thanks to the monopolistic policy - was guaranteed ${ }^{8}$, little was achieved regarding independent product development. With only one major design modification, Santana dominated SAIC's assembly lines as well as the Chinese market until recently, while in Germany its production stopped in 1993. Apart from its two joint-venture cash cows, SAIC barely has car production elsewhere. In 1999, it purchased a lossmaking plant in Yizheng city, Jiangsu province. Three years later Saibao was launched as SAIC's first branded car since 1958. This model was developed on GM's Opel platform. However, Saibao did not appeal to the market and was short-lived; its total sale in 2003 and 2004 was 4,298, less than 10\% of Chery's best-seller QQ in 2004 alone. In 2005 its production came to an end (Daily Economic Review, 15 Dec.2005).

SAIC's lack of technology and branding power is one reason it has resorted to offshore acquisition, which started shortly after the appointment of its new CEO Hu. The first big target was Ssangyong, the loss-making South Korean company. In 2003 SAIC bought $48.92 \%$ of Ssanyong's shares and became its controlling shareholder. In 2005, after giving up bidding on bankrupt Rover, SAIC paid £67 million on the technology details and IPRs of all of Rover's engines and its 75, 25 car series. It was hoped that the injection of new blood could enhance SAIC's weak technology basis. However, as Rover's equipments and human resources were bought by Nanjing Automobile (Group) Corporation (NAC), another well-connected last-minute bidder, SAIC encountered difficulties in mastering its newly purchased technologies: “....we now have four potential sources of technology, 1) Rover; 2) Ssangyong; 3) Ricardo in the UK (we pay them for engine design and technological consultancy); 4) our own joint ventures, Shanghai VW and Shanghai GM. Apparently we are doing a lot better...However we have a long way to go in understanding and integrating Rover and Ssangyong's organisation and technologies, plus we are still dependent on our partners in the two joint ventures for turnkey technologies - we were rejected by VW when we offered to buy its Santana platform after more than 20 years' co-operation", said a senior member of management (First Economic Daily, 03, Aug. 2005).

\section{Chery}

Chery's strategy can be summarised as a high degree of technological unbundling. In 1996 Chery bought its first manufacturing equipment from an outdated Ford engine factory in England and moved it to Wuhu. It also acquired manufacturing blueprints for a model called "Toledo" from a struggling VW subsidiary, SEAT, in Spain. In secret, the factory made its first engine in May of 1999. Seven months later, it turned out a car. It used Jetta parts, from suppliers who were supposedly exclusive to WW. 2000 cars named "Fengyun" were made that year. Since Chery did not have the license to produce or sell assembled cars, Wuhu government convinced its local taxi company to gulp the batch. In late 2000, Chery got hold of its first research team - a group of around 20 engineers who had previously worked for Dongfeng, another officially-supported company just like SAIC. Dongfeng's decision on closing down its research centre triggered their collective resignation. 8 months after coming to Chery, this team launched two new models, "Son of the Orient" and "QQ". The former looks like Volvo's "S80" and "QQ" reminds people of Chevrolet's "Spark". In fact, Chery's own team was only capable of design, or imitation of the bodies. The chassis were done by Tower (USA) and the majority of moulds by a Taiwanese company. In addition to producing engines on the Ford assembly line, Chery also receive external supplies. As for smaller parts like accessories, electronic devices and engine accessories, prototypes were provided by Chery to parts suppliers for batch production. By breaking down product technology to the most detailed elements possible, and by only paying for things that Chery could not do by itself, cost was brought

\footnotetext{
${ }^{8} 7$ of the 153 companies under SAIC make $85 \%$ profit and 5 of them are foreign partnerships (Financial Times, 21 April 2004, p.31).
} 
down. $Q Q$ was $1 / 3$ cheaper than its Chevrolet competitor and so was Son of the Orient. Both types became hits in the market and soon ranked as top-sellers.

After winning the first buckle of gold, Chery started investing heavily in R\&D and technological training. It is spending 10\%-15\% of its revenue on R\&D (Chery website March 06) and between 2000 and 2005' time its research division expanded to 11 departments with 800 staff. In order to cultivate its own development capability, Chery chose to work jointly with some of the most competent players, and its cooperation with AVL in Austria (the world's $4^{\text {th }}$ engine designer) is an example of this. Chery was responsible for initiating ideas and setting up standards while the latter specialises in designs and blueprints. "The most important foundation of our cooperation is that, we can ask any question regarding the technical details of their design and we can send our staff to observe and finally to participate" (Wang, 2005: 29). More than 100 Chery engineers went to AVL to take up training, some 900 others to other countries during the past years. The strategy of learning by training and learning by doing enabled Chery to develop the first China-made engine with its own IP. Compared to the large extent of pure imitation and reverse engineering in the previous phase, its new models, Tiggo, A5, F and M series obviously feature more in-house development.

\section{Guizhou Tyre Co.: a Long March to Endogenous Innovation}

\section{Methodology}

In this case study a combination of archive search (journal articles, news reports, and official statistics), site observations and cascade in-depth interviews was adopted to collect data. 5 semi-structured interviews were conducted in the firm and interviewees were selected according to their job responsibilities and knowledge of different aspects of the research question. Longitudinal questions regarding evolution of the firm's technological capabilities and its corporate governance were put to the Chief Executive, the Party Secretary 9 / Chief Operating Officer, the Chief Engineer, line manager and one of the shop floor operatives. Due to cultural reasons, tape recording was not conducted in interviews; however, detailed notes were taken with interviewees' signed consent.

Company history

Guizhou Tyre Co., Ltd (hereafter referred to as GTC), was founded in 1965 through the merger of Guizhou Tyre Factory with Grate China Rubber Company, which relocated in that year from Shanghai to Guiyang. In 1995, GTC was restructured as a shareholding firm and listed in 1997 in Shenzhen Stock Exchange. It is one of the 520 "key enterprises" (Zhongdian Qiye) selected by the State Council and one of the top 10 tyre companies in China. (See Appendix on tyre types and the Chinese tyre industry.)

GTC's main products include bias-ply tyre, radial-ply tyre, steel-belted radial tyre, heavy duty tyre, agricultural tyre, tubeless tyre and gas spring. $25 \%$ of its product is exported. By the end of 2005 it had 6,532 employees, 349 of which were technical staff. Its shareholding structure from May 2006 is: (non-circulated) state shares: $27.2 \%$, tradable shares: $72.8 \%$. Before this it was: state shares: $51 \%$, tradable shares $49 \%$. The state share reduction was operated through bonus issues to original holders as a gift (10:3.6). This is perhaps a neat expression of the fact that private property in a formal sense in China is less important than a clear recognition by the relevant people in power that one has the right to the yields from a particular asset. The state shares officially belong to Guiyang State Asset

${ }^{9}$ In Chinese state enterprises the secretary of the firm's communist party committee still remains powerful - he or she often holds key positions in senior management and is officially the ultimate decision-maker of staff hiring and firing. 
Management Co., Ltd, which is the provincial branch of SASAC; just as SAIC is owned by the Shanghai branch of SASAC.

Table 1. A snapshot of GTC's market performance

\begin{tabular}{lcc}
\hline & Jan. - Nov. 2005 & Increase from same period 2004 \\
\hline Gross Output & RMB 2.47 bn (\$298 million) & $22.46 \%$ \\
Total Production (Units) & $3,374,243$ & $5.26 \%$ \\
Total Sale (Units) & $3,041,613$ & $11.75 \%$ \\
Total Gross Revenue & RMB 2.78 bn (\$335 million) & $31.41 \%$ \\
Net Export & USD 64.83 million & $39.45 \%$ \\
\hline Source: GTC internal statistics (2006). &
\end{tabular}

Like most state-run enterprises in west China, in the 60s and 70s GTC almost had no technological input. In 1985 an engineer who had worked in the tyre industry for over 20 years became executive of this firm. GTC at that time was lagging behind its domestic competitors. One example is that its designed capacity in 1965 was 300,000 per year; however, GTC's annual output never reached that amount even 20 years later. With the help of the then supervising authority - the National Ministry of Chemical Engineering - Guilin Institute of Rubber Industry drafted a "ten-year development plan" for GTC, stating that it should "acquire and assimilate advanced foreign equipment and technology, adjust product structure, improve quality and realise economies of scale". GTC's major technological activity mainly revolved around this plan in the next decade (1986-96). A total of 220 million RMB was invested into technologyrelated activities such as the expansion of the heavy-duty tyre workshop, the light-weighting of nylon tyres and the purchase of a 1.05 million-capacity small tyre manufacturing line and the follow-up process innovations.

In less than 8 years GTC accomplished its first 10-year objective, sales increasing by $20 \%-30 \%$ annually, and it became the first and largest heavy-duty tyre producer in China. Seeing the higher profit margin of radial tyres, a second "10-year plan" was initiated, aiming at developing radial tyres capabilities while maintaining its advantageous position in the traditional bias tyre and heavy-duty tyre market. From 1996 to 2000 RMB1.05 bn was channelled from retained profit, government bonds, and bank loans (at subsidised interest rate) to acquire the capability to produce radial tyres. Product details were bought from Michelin and GTC designed the production line by itself. Key equipments were imported from different suppliers through a series of 4 biddings, and other complementary equipments were tailor-made by a private company in Tianjin. By the end of 2005 GTC's steel-belted radial tyre capacity has reached 1.5 million (the national capacity is 11 million), becoming the nation's $8^{\text {th }}$, and the only top 10 radial tyre manufacturer based away from the coastal area. The product was certificated with DOT, E-mark, ISO9001, and National 3C, and was given the official "Famous Brand Product" (mingpai chanpin) title in 2004.

\section{Unbundling}

"We have been always very conscious about our costs." says the Chief Executive, "we always use domestic machines if there is one available". The radial project is a case in point. In order to get the best value for money, instead of 
importing the complete set of machinery from Michelin, it asked its technical team to work out the most appropriate combination of equipment that would meet their needs and organised 4 international calls for tenders to get the key machines. In fact none of them were bought from Michelin. For complementary equipments they looked for cheaper substitutes in China. After carefully comparing the price, quality and after-sale service between over 30 domestic suppliers they finally gave the deal to a private Tianjin company. It later proved that these equipments were well adapted in production and each cut the cost by USD 3.41 million and RMB 4.43 million respectively. According to the purchasing plan drafted by Michelin, GTC needed to buy 7 forming machines for this new project which would cost over RMB 38.5 million. After studying the process of radial tyre production in both Michelin and Dunlop, GTC technical staff found out that if they could shorten the sulfuration time they wouldn't need to invest so much in equipment. 5 months later, the planned sulfuration process improvement was accomplished. This enabled GTC to cut their purchase of sulfuration equipment by 6 units, forming machines by 3 units, and in turn reduced the demand for radial parting moulds, which saved the group a total of RMB 29.46 million.

A retired tyre expert from Dunlop Australia was invited to work in the radial division as managing director between 1996 and 2003. GTC sent one of its deputy executives to work closely with him and to take over after he left. The CEO commented that the radial division enjoys highly autonomous and liberal management, largely inherited from the Australian manager. All medium level managers are university graduates and the division manager has HR rights to hire and fire people right under him. Wage rates are generally higher than for the same posts in other divisions and give more weight to workload rather than years of service.

R\&D expenditure in 2005 was RMB 140 million, thus $4.6 \%$ of its total turnover; by comparison, Michelin spends $4.2 \%$ in that year, according to GTC. "All the money that we got from our IPO was invested into technology activities," said the Party Secretary, Mr Qian, with emphasis. In 2003 GTC set up a post-doc station and hired two post-docs from Sichuan University to conduct research in the area of macromolecule materials. All living and travelling expenses were paid by GTC. Each post-doc was assigned three GTC technical staff, who were to provide assistance and support and on the other hand to learn by working closely with them.

GTC also spends generously on staff training. Around $1 / 4$ of employees from its two R\&D departments (the steelbelt radial project has its own $R \& D$ team) are now taking part-time degree-oriented studies, either at Qingdao University of Technology (MSc in macromolecule material) or at Guizhou University of Industry (MSc in mechatronics ${ }^{10}$ ). All tuition fees are reimbursed if staff pass all exams and receive the degree or $80 \%$ is reimbursed upon successfully finishing the course.

A visit to GTC's radial tyre plants was rejected due to secrecy concerns. However, according to observations in the heavy-duty tyre and bias tyre divisions, the standard of routine operation is high; for example, the rubber-kneading workshop is kept very tidy, which is hard for such type of process. Shop-floor workers mentioned that their working conditions have been constantly improved with ongoing technology and process fine-tuning, carried out by engineers from the R\&D department and themselves.

\section{Corporate Governance}

\section{'External' governance: relations of management with officials}

Although officially supervised by Guiyang State Asset Management Co., Ltd which is an independent entity, GTC still perceives itself as a state firm closely associated with the local government: "We were very lucky to be favoured as

${ }^{10}$ This is a new field of technology combining mechanics and electronics. This concerns the elements of advanced manufacturing production technologies. Mechatronics covers the fields of advanced robotics, FMS, CAD/CAM, intelligent mechanisms, or the elements of advanced manufacturing technology. (www.iciba.com) 
'number one' by the Guiyang government; it makes our life a lot easier. We received financial supports such as interest subsidy on bank loans in our radial project in the 90s. Even now when subsidy is no longer allowed, we can still get our projects approved by the bank much more easily than other local companies since we have the local government as our guarantor. And it is not only about that, there have been times when problems cannot be solved by us, and the senior officials played crucial roles to sort things out. Because we are doing quite well now especially in a remote province like Guizhou, the central government starts to notice us and has listed us in the mid-long-term Agenda of the National Technology Development, which will provide us tax benefit. It has a crucial meaning because we feel that in the period of growing competence it not only gives us the financial edge but also political support." The Party Secretary of Guizhou province and Guiyang city and the Mayor often come to GTC, sometimes spending a whole day working on the site. "...the Mayor once said if our output reaches RMB 5 bn he will give us this and that. We don't know if he really means it, and we doubt if he could do so because of the financial constraint that Guizhou faces as a whole, but at least we know that he cares about the whole thing and would be pleased if we could ..." (GTC's output in 2005 was RMB 3 bn and according to the CEO 5 bn could already be reached in 2010)

Mr Ma Shichun, aged 71, has been working in the tyre industry for over 38 years and has remained chief executive since 1986. Apart from the stated salary, he and a few other senior managers also receive discreet remunerations from the local government. At the end of 2004 the amount paid to Mr Ma was RMB 1 million, while average net income in this company was less than 10,000 per year, and while the bonus paid to the company for their winning the "famous brand" title for radial tyres was RMB 300,000. However, this pay package is unofficial and is thus subject to the officials' discretion. At the end of June $06 \mathrm{Mr} \mathrm{Ma}$ and his peers were still waiting for the payment for year 2005 and were not sure whether it would eventually come.

Performance measurement is conducted both on an annual and irregular basis covering a wide range of criteria, including political stability, gross and net profit, employment, staff income, tax contribution, market share and export, etc. However, nothing is directly related to technological performance. The CEO believes that it is reasonable: "the leaders are very busy and are in charge of thousands of firms, making tyres is a very complicated thing, we cannot expect them to understand what we are doing, and all we can expect is autonomy and support".

\section{'Internal Governance': relationships within the firm}

$\mathrm{Mr} \mathrm{Ma}$, a Shanghai-born university graduate who has worked in GTC for over 30 years, is widely respected and regarded as the core of this enterprise. His name was mentioned by almost all interviewees with admiration: "if our enterprise were to be imagined as an innovative machine, then $\mathrm{Mr} \mathrm{Ma}$ is the crucial axis that makes the machine start and work properly", says the principal engineer/ deputy chief executive, aged 37. He was thought to be able to make important, right strategic decisions at the right time. For example, lorries in China are seriously overloaded, and ordinary tyres are not durable enough. Ma asked research staff to modify the formula of the heavy-duty tyres and sold them to the replacement market. Sales increased dramatically and the profit was later injected into their new radial tyre project, partially solving the fund-shortage problem. It was proved that such strategy secured GTC's market competitiveness. He is also a diligent practitioner of 'management by walking about': shop-floor operatives are very familiar with him coming into the workshop and consulting them on strategic decisions.

Mr Wang also believes that sufficient autonomy has been given to the technical staff: "we are encouraged to carry out experiments and trials, and don't need to worry about any fine or punishment if we fail..."

All senior managers have worked in GTC for at least 10 years and many of them have been on the post for more than 10 years. "We think it is very important that we have a relatively stable management team. I give you an example, 
there is another firm, for some reasons their senior managers were changed almost once every 6 months, and now the firm is just about to go bankrupt, surely there are many other reasons for this, but what a pity..." said Mr Qian, who started his career at GTC in 1965 and became Party Secretary in 1997.

Inclusion Factors:

As a state-owned company in Guizhou, GTC has relatively high wage rates. Salary consists of two parts: basic pay and performance pay. Shop floor operatives are paid according to their qualifications and workload, requirement for skills and job hazard. Maintenance workers are paid slightly more than others. However, skilled workers still tend to leave: "working in a tyre-making factory is a tough job, but we are not too worried about shop-floor workers, they are more or less attached to their jobs due to technical reasons (although we have a job-rotation scheme) and it is not too difficult to recruit young peasants from the countryside. It is maintenance workers that we are more concerned about at the moment. It's a much more skilled job and it takes longer to train qualified staff. The nature of their jobs in our firm means that they must be very dedicated; there is hardly any time to sit down and chill out in a day. For the same money they can find much easier jobs in other factories, either in Guiyang or in other big cities." Mr Wang admits that continuous loss of skilled maintenance workers has had an impact on the firm.

Technical employees have special bonuses based on their qualifications, experience and job titles. Project leaders enjoy an extra subsidy of 1000 Yuan/month. GTC also has various awards for outstanding technical performances: product development/innovation, process improvement, cost-reduction, etc. The highest award is cash RMB 50,000. The award committee is mainly composed of senior engineers and experts from research institutes and universities, while GTC's senior management is not involved in the selection process.

Firm-level "model workers" are rewarded very generously as well: RMB 4,800. In contrast, a province level "model worker" only receives RMB 800 from the provincial trade union. "There are problems with that. I heard a lot of complaints. In some factories different workers are selected for these two awards to show so-called 'equality', and they end up receiving different benefits..." said Mr Wang.

GTC is also seeking opportunities for technological collaboration with research institutes and universities. It now has ongoing projects with China Science Academy and Qingdao University of Technology, and according to the contracts GTC owns the IPRs. Also, GTC relies heavily on retired experts from overseas to tackle unsolved technical problems. There is no formal collaboration with other firms, but on the other hand, according to Mr Qian, informal information flow (Macdonald, 1992) from peer research staff in competitor firms has always been active and largely contributed to the growth of GTC's technological capabilities.

Three key problems that GTC is still grappling with are the surplus of manual workers and lower-level administrative staff that it is not allowed to fire, because of the poor employment situation in Guizhou; its rather poor brand reputation due largely to being a domestic firm in an unfashionable location; and its lack of basic R\&D capacity which would allow it to tackle challenges like making full use of glass fibre.

\section{Discussion and Concluding Remarks}

We argued that three factors, engagement, expertise and inclusion in corporate governance affect a firm's strategy and behaviour in technological capability building. We began with a view of the 'typical' Chinese SOE as handicapped by the lack of engagement and expertise among controlling officials, and (partly in consequence) as having poor inclusion of employees and other stakeholders. It did, on the other hand, enjoy access to large amounts of cheap bank loans, particularly if it was a firm favoured by central government. All these factors conduced to strategies of 
technological bundling. The findings of our first case study fit precisely into this expectation: SAIC has had a problematic governance structure. Government parachuted its officials into the company who did not necessarily have industrial expertise, and they were moved away not long after. Managers came to their posts with assigned tasks, either to increase capacity or to enhance profit; anyway, both are quantitative, highly visible and easy to measure. Since they did not have much time, nor did they or those monitoring have sufficient expertise, it was sensible for them to choose bundled technologies which came from MNC partners - these are easy to understand, readily available, and fast in effect. Now threatened by competitors such as Chery, and having a CEO who came up from within the organisation and who has the potential to stay, SAIC started to try to fight its way out. Its advantage is that it need not worry much about its budget; therefore it is able to buy not only technologies but also organisations that own the technologies. It is too soon to say whether it will succeed, but at least this offers an alternative to its previous practices.

Chery by contrast followed a strategy of extensive unbundling, which so far has been strikingly successful. How can we explain this in terms of its governance? Certainly not in terms of superior expertise among monitoring officials. What did the local Party hierarchies of Wuhu and Anhui know about the motor industry? Engagement, then? Undoubtedly Chery got a great deal of attention from the highest officials in Wuhu and Anhui. Lacking expertise, however, it is hard to believe that, however closely they engaged, they would have been able to judge the quality of Yin Tongyao's strategy. What they did was simply to take some trouble to pick the right man, highly experienced in the industry, and then to back him while he built them a successful motor firm from scratch. For this they gave him time (we do not know how much) and money - but certainly not much of the latter. As Hu Maoyuan of SAIC is alleged to have said when criticised for not following Chery's road, they did it that way because they had to: unbundling was a great deal cheaper. (It is plausibly rumoured that the teachers of the whole province of Anhui had to wait several months for pay at one point, when Chery got one of its largest cash infusions: Anhui is dirt poor compared to Shanghai.) Chery's market position followed from its shortage of resources: they started at the bottom end of the market, where their low prices were most appreciated and their low initial quality most forgiven. Yin Tongyao, not having to watch his back, could watch his front: he could concentrate on building strong relationships with employees and suppliers. In sharp contrast with large-scale SOEs, staff expertise and inputs were treasured and their potential explored during the process of learning. Chery again wins higher marks for employee inclusion. Chery may also have gained from its complete insignificance in its early years. Who cared what those hicks in Wuhu (where?) were doing? Who was watching when, within their unbundling strategy, they made what might be called questionable moves on others' intellectual property?

Chery's current success also has implications for SAIC's strategy. SAIC's old strategy is discredited, but it does not have to follow Chery's style of unbundling. As we have seen, at the end SAIC was buying foreign technology by buying the firms that owned it, and could spend heavily on R\&D to fill any gap in what it bought. As a large enterprise with strength in finance and experience of large-scale production of high quality, SAIC can take the 'high road' while Chery (initially at least) had to take the 'low road'.

Our in-depth study of GTC strongly confirms our relatively tentative inferences from Chery. GTC is to Guizhou province and its capital Guiyang, much as Chery is to Anhui and Wuhu: a poor family's favourite child. Again, the relevant officials picked the right man - an experienced tyre engineer and manager - and stood by him. Like Yin Tongyao, Ma Shichun did not have to watch his back. Even more clearly, he was given time to deliver though initially little money. (The shortage of money was compounded by the need to 'carry' surplus employees.) Hired in 1985, he was still in charge 20 years later and with no end of his tenure in sight - a dramatic difference from the traditional SOE rotation of officials doing a stint as an industrial manager. How expert and engaged the monitoring officials have been over the years it is hard to tell, and the evidence suggests, not very, but in this context it hardly matters: Mr Ma was 
very expert and very engaged and in effect, though not in any formal sense, he was a major shareholder of the firm: he could have every confidence that he would be handsomely rewarded if it succeeded, and he was. Clearly Mr Ma's time horizon was very long: he had every opportunity and motivation to aim for real technological capability development and he did so. The endogenous growth is clearly built on thorough and intelligent unbundling, as illustrated by the radial tyre project, including the use of the retired Australian.

Under Mr Ma, there has been a great deal of inclusion, formally and informally. The Party organization within the firm (one of the laosanhui, 'old three organizations' that controlled the firm) seems to continue to function and to do so in harmony with Mr Ma. (Not only can a good Party secretary - who in this case doubled as Chief Operating Officer help to make relationships run smoothly within the firm, he can do the same for important relationships outside the firm, above all with senior officials.) There is a stable management team. Shop-floor workers are made to feel included partly by Mr Ma's practice of Management by Walking About, partly by the care taken to reward valuable contributors. (The loss of skilled maintenance workers is however a point on the other side.) GTC's close cooperation with various domestic universities and the national academy of science is evidence, if not of stakeholder inclusion, then at least of careful nurturing of important relationships. Likewise, the informal flows of information from rival firms can only be fully beneficial if those in the firm whose personal networks carry them, are fully committed to the firm.

We conclude that our general thesis about the flaws in the corporate governance of Chinese SOEs is supported by our three case studies. SAIC conformed to 'large favoured SOE' type, in the characteristics of its corporate governance and its easy access to funds. It conformed to type, too, in the strategy of technology bundling that it followed, and in that strategy's poor results. Chery and GTC are most untypical in their success in developing 'endogenous' (or 'indigenous', or 'self-reliant') technological capability, and in the unbundling strategies that led to it. They turn out also to be untypical in terms of external corporate governance - in the highly-engaged behaviour of the government levels concerned, and (crucially) in the autonomy and time given to the top managers. This led them to follow strongly-inclusive policies within the firm. It is interesting to compare our findings here with those of Cai and Tylecote (2005), who found an advantage in minority state ownership, which gave room for top managers (and conceivably other employees) to hold a major stake in the enterprise. Both GTC and (so far as we are aware) Chery were during the period studied, wholly-owned state firms. But what is, or was, the real difference? From a conventional Western point of view, a large share stake gives a manager secure power and a clear-cut financial interest in the firm: its success means riches for the manager. But Yin Tongyao and Ma Shichun had that position without shares. Affluence and power in China have been better secured by official favour than by entries in share registers. Minority SOEs will no doubt be excellent vehicles for technological dynamism in future, property rights being now rather more secure. But the moral of our story for China is that regardless of formal institutions, the key underlying relationships need to be conducive to the right technology strategies.

\section{References}

Arora, A. (1996) Contracting for tacit knowledge: the provision of technical services in technology licensing contracts, Journal of Development Economics, 50(2), pp.233-256. Barney, J. B. (1991) Firm resources and sustained competitive advantage, Journal of management, 17(1), pp. 99-120. Bell, M.R. (1984) "Learning" and the accumulation of industrial technological capacity in developing countries. In M. Fransman and K. King (eds.). Chery's official website, [Accessed March 2005 - September 2006], available from World Wide Web: <http:// www.chery.cn > Financial Times, 21, April 2004.

First Economic Daily (in Chinese, Diyi Caijing Ribao), 03, August 2005, Available from World Wide Web: <http://dycj.ynet.com> Gallagher, K.S. (2003) Innovation and learning in the Chinese auto industry through technology transfer, mimeo. Gu, S. (1999) China's Industrial Technology, Market Reform and Organisational Change (London and New York: Routledge /UNU Press). Harwitt, E. (2001) The impact of WTO membership on Auto industry in China, The China Quarterly, 167, pp. 655-670. Hessler, P. (2005) Car town, The New Yorker, September 26, p.90. 
Hillerbrand, W. et al (1994) Strengthening technological capability in developing countries, Working Paper in German Development Institute (GDI), Berlin.

Huq, M.M. (1999) Technological capability building in low-income developing countries, Working paper of the University of Bath.

Itter, C.D. and Larcker, D.F. (1997) Quality strategy, strategic control systems and organisational performance, Accounting, Organisations and Society 22(3/4), pp.293-314.

Jensen, M. And Meckling, W. (1976) Theory of the firm, managerial behaviour, agency costs and ownership structure, Journal of Financial Economics, 3(4), pp. 305-360

Jin, L. (2004) Qirui Jiechuanle Woguo Qicheye de Liangge Shenhua (in Chinese, Chery shattered two myths about China's automotive industry), Automotive Information, 23.

Kumar, V. et al. (1999) Buiding technological capability through importing technology, The Journal of Technology Transfer, 24(1), pp. 81-96.

Lall, S. (2001) National strategies for technology adoption in the industrial sector, For the UNDP 2001 Human Development Report

Lee, C. et al. (1996) Different strategies of localization in the Chinese auto industry, Working Paper for the MIT 1996 IMVP Sponsors Meeting Sao Paulo, Brazil 9-12 June 1996. Available from World Wide Web: <http://hdl.handle.net/1721.1/1607>

Lu, F. and Feng, K. ( 2004) Fazhan woguo zizhu zhishichanquan qichegongye de zhengce xuanze (In Chinese: The Policy Choice in Developing China's Proprietary Car Industry) (Beijing: Beijing University Press)

Macdonald, S. (1992) Formal collaboration and informal information flow, International Journal of Technology Management, 7, pp. 49-60.

Nalebuff, B. (2004) Bundling as an Entry Barrier, Quarterly Journal of Economics, 119(1), pp.159-187.

OECD. (2004) OECD Principles of Corporate Governance (Paris, OECD).

Peteraf, M.A. (1993) The cornerstones of competitive advantage, Strategic Management Journal, 14(3), pp. 179-191.

Rosenberg, N, and Frischtak, C. (1985) International technology transfer (New York: Praeger)

SAIC's official website, [Accessed March 2005- September 2006], Available from World Wide Web: < http://www.saicgroup.com>.

Teece, D. J. et al. (2000) Dynamic capabilities and strategic management, in DOSI et al. (eds), The nature and dynamics of organizational capabilities (Oxford: Oxford Press)

Tylecote, A. and Cai, J. (2004) China's SOE reform and technological change, Asian Business and Management, 3(1), pp. 57-84.

Tylecote, A. and Conesa, E. (1999) Corporate governance, innovation systems and industrial performance, Industry and Innovation, 6(1). pp. 25-50

Wang, G (2005) Tansuo Zhongguo Qiche Zizhukaifa zhi Lu (in Chinese, In search of the approach to proprietary innovation), Science and Technology in China, 2.

Wang, H. (2001) Policy reforms and foreign direct investment: the case of the Chinese auto industry, 9th GERPISA Colloquium, Reconfiguring the Auto Industry, 7-9 June, Paris, France

WU, Q. (2005) Qirui: 750 ren yinshen zhongguo zhizao (in Chinese, Cherry: 750 invisible persons, building 'Made in China'), Meiri Jingji Guancha (in Chinese: Daily Economic Review), 15, Dec. p 7. 


\section{Appendix}

\section{Tyre Types and the Chinese Tyre Industry}

A radial tyre (more properly, a radial-ply tyre) is a particular design of automotive tyre. The design was originally developed by Michelin in 1946 but, because of its advantages, has now become the standard design for essentially all automotive tyres.

Tyres are not fabricated just from rubber; within the rubber are a series of plies of cord that act as reinforcement. In the past, the fabric was built up on a flat steel drum, with the cords at an angle of about +60 and -60 degrees from the direction of travel, so they criss-crossed over each other. They were called cross ply or bias ply tires. The plies were turned up around the steel wire beads and the combined tread/sidewall applied. The green (uncured) tire was loaded over a curing bladder and shaped into the mould. This shaping process caused the cords in the tire to assume an $\mathrm{S}$ shape from bead to bead. The angle under the tread stretched down to about 36 degrees. This was called the Crown Angle. In the sidewall region the angle was 45 degrees and in the bead it remained at 60 degrees. The low crown angle gave rigidity to support the tread and the high sidewall angle gave comfort.

By comparison, radial tires lay all of the cord plies at 90 degrees to the direction of travel (that is, across the tire from lip to lip). This design avoids having the plies rub against each other as the tire flexes, reducing the rolling friction of the tire. This allows vehicles with radial tires to achieve better fuel economy than vehicles with bias-ply tires. It also accounts for the slightly "low on air" (bulging) look that radial tire sidewalls have, especially when compared to biasply tires.

Radial tyre has been widely produced and used as the main-stream product; the average radial rate of tyres used in car manufacturing has reached $90 \%$, while in developed countries this figure is nearly $100 \%$. In China research projects on radial tyre can be traced back to the mid 60s, however, mass production only started in 1996 . With in 7 years of expansion by 2003 total radial tyre production has reached 75 million, of which steel-belted 11 million (GTC has 1.5 million) and radial rate of car tyres $60 \%$. 
Figure 1. Structure of Tyre Production in China in Year 2005 (100 million units)

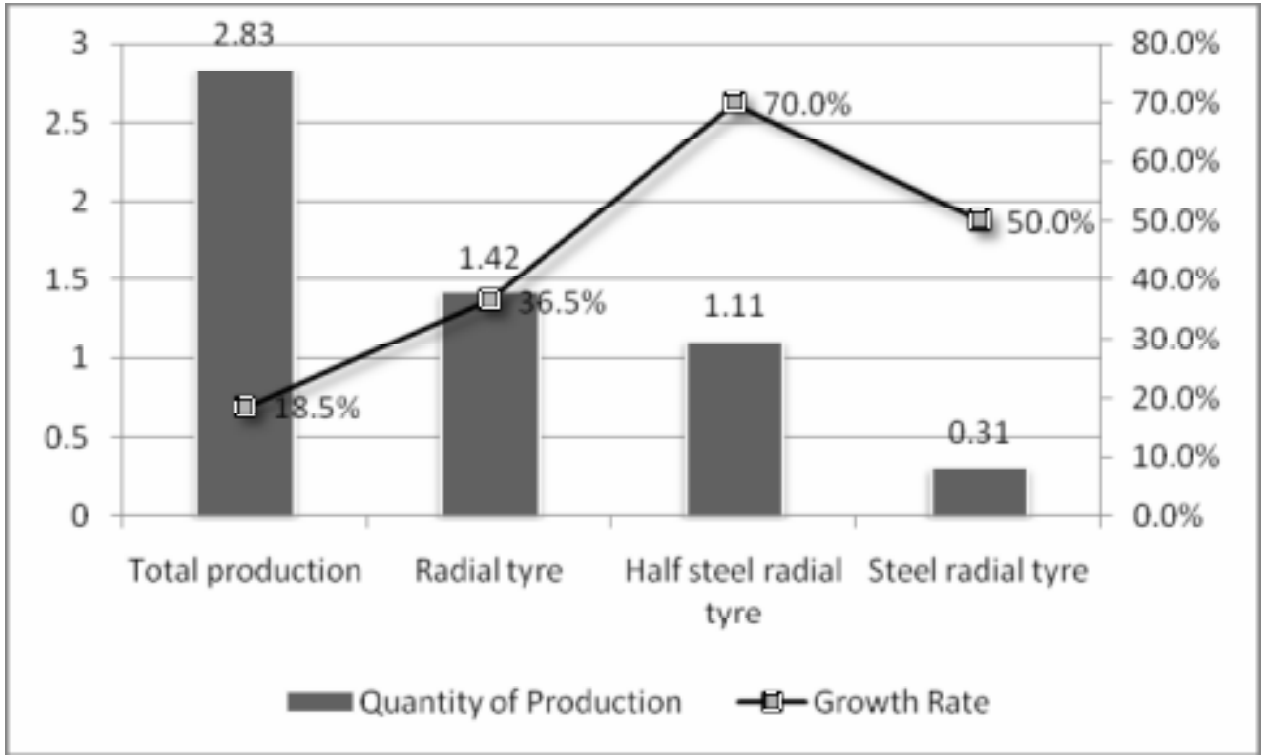

Source: Data from Heading Century Consulting Co., Ltd (http://www.heading-century.com)

Figure 2. Production of Radial Tyres in China, Years 2003-2005 (100 million units)

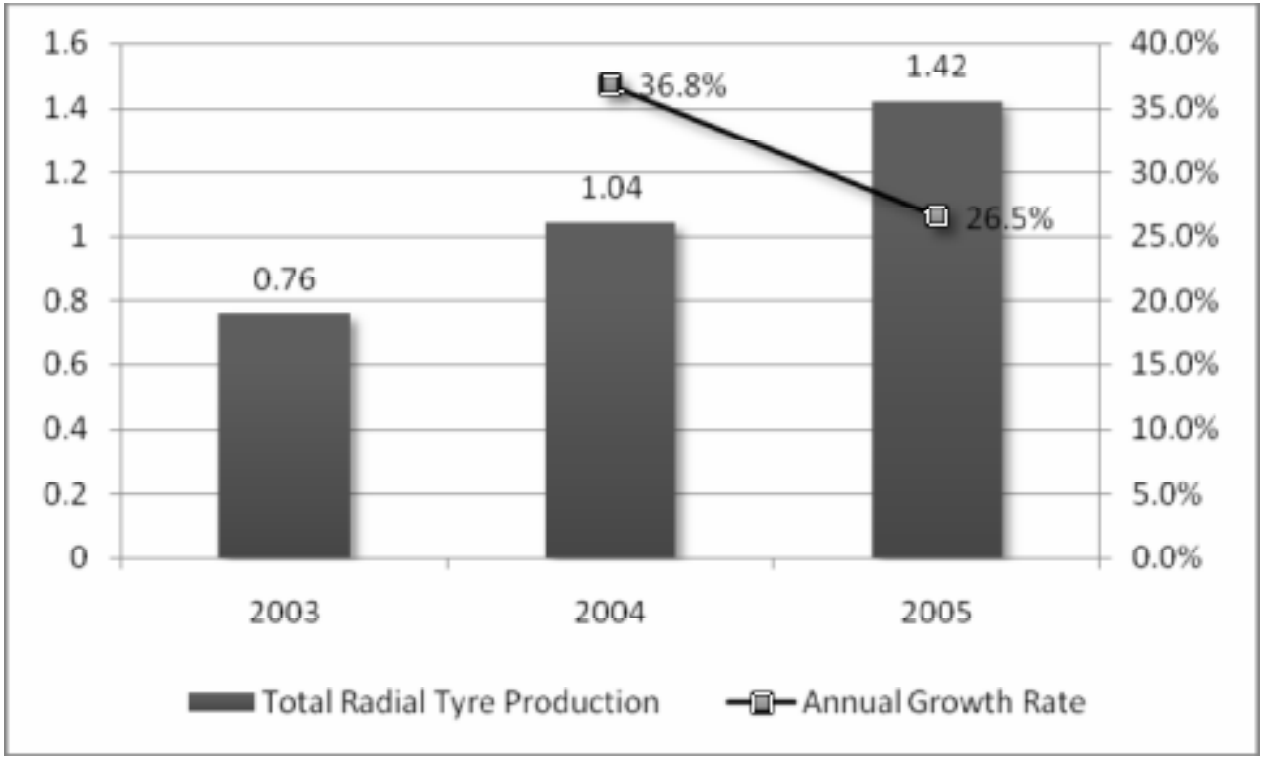

Source: Data from Heading Century Consulting Co., Ltd (http://www.heading-century.com) 
Andrew Tylecote, Jing Cai and Jiajia Liu, 'Why are Mainland Chinese

Firms Succeeding in Some Sectors and Failing in Others? A Critical View of the Chinese System of Innovation'. International Journal of Learning and Intellectual Capital, 7 (2) pp.123-144, January 2010.

\author{
Professor Andrew Tylecote \\ Management School \\ Sheffield University, UK
}

Fax: 01142223348

Email: a.tylecote@shef.ac.uk

Dr. Jing Cai

Department of Management Studies

University of Aberdeen Business School, UK

Fax: 01224212

Email: jing.cai@abdn.ac.uk

Jiajia Liu

Management School

Sheffield University, UK

Fax: 01142223348

Email: Jiajia.Liu@sheffield.ac.uk

\title{
Biographical notes:
}


Andrew Tylecote has been Professor of the Economics and Management of Technological Change at the University of Sheffield Management School since 1994. He was educated at Oxford and Sussex in philosophy, politics, economics and sociology, and has long worked on the effect of institutional factors on economic performance, focusing recently on the effects of finance and corporate governance, broadly defined, on technological change. He led a six country EUfunded study of this in 1998-2002 and since then has extended the work to China, with Visiting Professorships at Tsinghua and Zhejiang University.

Dr. Jing Cai is a lecturer at the University of Aberdeen Business School. She has been working with Andrew Tylecote since 2001 on the effect of finance and corporate governance on Chinese firms' technological capability. She is also a coinvestigator of a study 'Corporate Governance and Technological Development in China', funded by the UK Economic and Social Research Council, led by Andrew Tylecote and in collaboration with Professors Wu Guisheng (Tsinghua University) and Fang Lee Cooke (Manchester University).

Jiajia Liu is a PhD student supervised by Andrew Tylecote at the Management School, University of Sheffield. Before coming to the UK, she was a lecturer of Economics at Shanghai Finance College, China. From 2005 to 2007, she was the research assistant of the project: 'Corporate Governance and Technological Development in China'. 
Abstract: Domestically-owned firms in mainland China have shown disappointing technological performance in higher-technology sectors. We argue that deficiencies in the system of finance and corporate governance are largely to blame. Private firms have been starved of financial resources. The key weakness of Chinese state-owned firms (SOEs), lies in their corporate governance: officials monitoring them have been 'disengaged', with the consequence that investment of money and effort which was low in visibility ('opaque') and/or slow in pay-off, has been discouraged. 'Disengagement' also discourages development of close inter-firm relationships, and employee 'inclusion'. We examine a small number of sectors, notably telecoms and motor vehicles, in which Chinese firms appear to be doing well, showing that 'untypical' corporate governance produces untypically good results. We conclude by warning against relying, in monitoring large SOEs, on financial accounting measures, pointing to the British example. China should find Chinese ways of achieving engagement and inclusion.

Keywords: China, National Systems of Innovation, Finance, Corporate Governance, Inter-firm Relationship. [148 words] 
A. Tylecote, J. Cai and J. Liu

\section{Introduction}

The brilliant success of the mainland Chinese economy in terms of aggregate output, and output per head, may obscure the technological weakness of mainland China's own firms. In this paper we set out the evidence for such weakness, which is general though not universal across medium and high-technology industry, and then analyze its causes. We argue that in any national system of innovation (or technological learning) firms are key, and the most important factors which affect them are their governance and finance, while a key aspect of the behaviour are their relationships, particularly with other firms. We set out an analytical framework for understanding the effect of governance and finance on firms' technological learning in a developing country. We then examine corporate governance and finance in mainland China, particularly the governance of state-owned enterprises (SOEs), and their effects on the

Chinese national system of innovation. We argue that a key weakness of Chinese SOEs lies in their corporate governance, very broadly defined (as 'who controls them, and how'): officials monitoring them have been 'disengaged', with the consequence that investment of money and effort which was low in visibility and/or slow in pay-off, has been discouraged. What is favored, on the other hand, is the purchase of 'packages' or 'bundles' of technology (and the equipment which 'embodies' it) from foreign firms in advanced economies. 'Disengagement' also discourages 
Why is Mainland China Rising in Some Sectors and Failing in Others?

development of close inter-firm relationships, because they require effort which is low in visibility and slow in pay-off. The exception tests the rule: we examine a small number of high and medium high-technology sectors, notably telecoms and motor vehicles, where Chinese firms either have been successful already (telecoms), or are showing good promise (vehicles). We look at a number of cases in both sectors which show that 'untypical' corporate governance produces untypically good results. We

conclude by looking at recent developments in the mechanisms government uses to monitor large SOEs. While in general movements towards Western models of market economy may be desirable, the developments we look at here threaten (we argue) to replace one form of disengaged control by another.

\section{The technological strengths and weaknesses of Chinese businesses}

Gu and Lundvall (2006, p.10) sum up the Chinese position (as of 2005): 'The industrialization process has not resulted in building a widespread and robust indigenous innovation capability in Chinese firms. ... China's economy has not been able to embark upon the competence upgrading track. China remains specialized in low value-added products...' There is all too much evidence in support of this proposition. Patenting is one element of it. Mahmood and Singh (2003) show that patenting is a 


\section{A. Tylecote, J. Cai and J. Liu}

reasonable indicator of overall technological capability in developing as in developed countries. The remarkable Taiwanese drive up-market, for example, is mirrored by its patenting performance: from 176 US patents in 1975-79 through 1772 in $1985-89$ to 12,366 in 1995-99 (their Table 2). In the same period mainland China - some 40 times larger in population went from 2, through 129, to 332 US patents.

Equally striking, though at first sight mystifying, is the difference in patterns that Mahmood and Singh (2003) find at sectoral level (their Tables 7 and 9). In 1995-99 the five top sectors in Taiwan, in revealed technological advantage (RTA: relative patent share) quite closely reflected Taiwan's areas of specialisation so far as production and trade are concerned. Contrast mainland China, whose five top sectors in RTA terms in 1995-99 were: Miscellaneous chemical products; Basic industrial chemicals; Ship/boat building and repairing; Agricultural chemicals; Drugs and medicine. With the possible exception of shipbuilding, there is no sign of any mainland Chinese export drive in any of these areas. Chemicals (together) have been below $10 \%$ of Chinese exports since 1980, with a downward trend ( $\mathrm{Gu} \&$ Lundvall, 2006, Figure 5). Conversely, where is the Chinese patenting strength in the sectors where their exports have surged? The explanation for this oddity is simple: Chinese export successes are not, for the most part, based on technological 
Why is Mainland China Rising in Some Sectors and Failing in Others?

capability. Exports by Chinese firms are mainly in the labour-intensive, low-technology areas like textiles and clothing. Mainland China as a location is doing very well as an exporter in some high-technology sectors - electronics, notably. The share of high-technology exports in total exports rose from $7.9 \%$ in 1995 to $29.9 \%$ in 2004 . [www.stats.gov.cn/tjsj/qtsi/zgktjni] But the Made in China label on finished goods conceals the fact that most of the machinery with which they were made, and their key components, were imported - mostly from elsewhere in East Asia. And most of its so-called high-technology manufacturing is under foreign ownership or at least control. In 2003 $61.9 \%$ and $21.4 \%$ of high-tech exports were produced by fully foreignowned and partly foreign-owned firms respectively ( $\mathrm{Gu} \&$ Lundvall, 2006citing China S\&T Indicators 2004). Between 1998 and 2005 the share of Chinese-owned firms (aside from joint ventures) in exports of high-tech products fell by more than half (www.sts.org.cn/sjk1/kjtjdt/data2006, Fig 2-10) while that of wholly foreign-owned rose year by year. $\mathrm{Gu}$ and Lundvall (2006) mention one sub-sector of electronics, TV manufacturing, in which mainland China (including some Chinese-owned firms) has a 'well-developed competitive advantage', but in which value-added is low because key components are imported from elsewhere in East Asia, and profit margins were as of 2005 around or below 3\%. An indicator of the domestic Chinese weakness is the $R \& D$ intensity, since $R \& D$ tends to be 


\section{A. Tylecote, J. Cai and J. Liu}

performed near a firm's home base: the R\&D intensity (over value-added) of high tech industries overall, in mainland China, was $4.6 \%$ in 2004 (cf. $27.3 \%$ in US, $29.9 \%$ in Japan, in 2002). (www.sts.org.cn/sjk1/kjtjdt/data2006, T1-15.) The breakdown by sector is even more instructive: for aircraft and spacecraft the intensity was 16.9, comparable to the US figure $(18.9 \% 2002)$; but this sector is very small and dominated by state-owned firms (T1-5). For electronic and telecommunications equipment the corresponding figures are 5.6 (US, 25.4) and those for computers and office equipment, 3.2 (US, 32.8). (These two sectors together made up $72.4 \%$ of the value-added of hightechnology industry in China in 2004 - the other sectors, in descending order, being pharmaceuticals, medical equipment $\&$ meters, and aircraft $\&$ spacecraft.)

There are scale-intensive industries where large, profitable, and reasonably efficient state-owned firms can be developed on the basis of a very large protected home market, and access to very large amounts of cheap longterm capital, which state-owned firms have consistently enjoyed (see below). This explains the three big Chinese oil and gas companies, Petrochina, Sinopec and CNOOC, now investing across the world; Baosteel, China's largest steel producer; Chalco, its largest aluminium producer; China Minmetals, its biggest base metals company. 
Why is Mainland China Rising in Some Sectors and Failing in Others?

There are, likewise, labour-intensive low-technology industries in which it is easy for new private entrepreneurs to set up, and where with a huge pool of cheap and disciplined labour, plus a decent trading infrastructure, agglomerations of Chinese producers now dominate world markets. There are industrial districts, large and small, concentrating for example on socks, on chairs - and on software (Van Dijk \& Wang, 2005). But Gu (2003) firmly denies many of these agglomerations of businesses the name of clusters - because clusters should have some kind of dynamic coherence, with cooperation as well as competition among their member firms. Some do; most do not.

There is, in the last analysis, only two major sectors, and one minor one, in which Chinese development of technological capability has been impressive. The minor sector is digital video players $(\mathrm{Lu}, 2005)$. The major sectors are telecommunications, led (in commercial terms) by Huawei, which in 2004 gained $40 \%$ of its over \$5bn revenues outside China (see Figure 2), and motor vehicles, which unlike telecommunications has only in the last few years become technologically dynamic. We shall consider below how these exceptions can be explained. We shall throughout the discussion give most emphasis to state-owned enterprises (SOEs) because it is these which have had the scale, the 
A. Tylecote, J. Cai and J. Liu

experience and the resources without which, in most sectors and subsectors, it is impossible to take on real technological challenges.

\section{Key determinants of technological learning by firms in developing economies.}

\subsection{Firms in national systems of innovation}

National systems of innovation, being systems, involve interactions among their component parts. The institutions which have scientific and technological progress as their raison d'etre, universities and research institutes, are important components; so of course is government, partly because it mostly funds and largely directs these institutions (eg. Nelson, 1993). Firms are however the core of any market economy, and thus the core of the NSI in any market economy - which China now is, predominantly. As such, government's impact on the NSI is mostly through its impacts on firms. In any economy, and particularly one emerging from full state control like China, industrial policy will have an important role in the NSI (Nolan, 1996, 2001). The extent and nature of competition is likewise important, and any shielding of firms from it by a 'nurturing' state will have important, and largely deleterious, effects (Lu \& Feng, 2004). However in a capitalist economy, the source and nature of firms' capital (finance) and the source and mechanism of power over firms (corporate governance) are, we believe, most important of all (Tylecote, 
Why is Mainland China Rising in Some Sectors and Failing in Others?

2007; Tylecote \& Visintin, 2008). There is powerful support for this view in the innovation literature on developed economies, beginning with Schumpeter (Schumpeter (1911/1996) on finance; Schumpeter (1942) on corporate governance). ${ }^{1}$ It is also quite consistent with Porter (1990). In ch.3 of Competitive Advantage of Nations he addresses the role of finance and corporate governance directly. In ch.4, he shows how it affects the relationships among firms. We do not seek here to exclude other factors from consideration, but to show how useful explanatory factors finance and corporate governance can be in the Chinese case. In this section we shall focus on two issues. The first is, how corporate governance and finance affect technological learning in a developing economy. The second is, what shapes the relationships of firms in a developing economy, and how their relationships affect their learning. Given their interactions within the system of innovation, this appears to us to be crucial too. We shall see that the two issues are quite closely linked.

\subsection{How corporate governance and finance affect technological learning} in a developing economy.

A framework for analysing the effects of corporate governance and finance on technological change in developed countries has been put

\footnotetext{
${ }^{1}$ On the role of finance in the NSI see also Christensen in Lundvall (eds) (1992) and Pavitt (1999).
} 


\section{A. Tylecote, J. Cai and J. Liu}

forward in various formulations by Tylecote and Ramirez (2006), Tylecote (2007) and (Tylecote \& Visintin, 2008). In this framework the challenges of technological change to the financial and corporate governance system are fourfold. In a developing country they can, with some simplification, be reduced to two:

1. Opacity/slow pay-off. The process of technological learning is typically opaque: an outsider cannot easily understand what is going on. Sometimes it is not even clear what is being spent, in money and effort, and universally it is uncertain for a considerable period what if any return there will be on that money and effort. There is then an acute case of the information asymmetry which has long been seen as a key problem of corporate governance. (Jensen \& Meckling, 1976). Opacity and delay vary according to the sector and the strategy adopted - but strategies involving less opacity and delay are likely to involve relatively superficial learning (see below). Opacity can be countered by engagement, which gives the ability to look below the surface: thus the ownermanager of a small firm should understand what is going on in his/her firm, while an outside shareholder of a large firm might well not (see below). Understanding should give tolerance of delay. Alternatively, managers who have autonomy from shareholders 
Why is Mainland China Rising in Some Sectors and Failing in Others?

can tolerate a long time to pay-off.

2. Stakeholder spill-overs Technological learning often requires inputs of money and (above all) effort from stakeholders employees and related firms - which cannot easily be monitored or defined in advance and so cannot be well dealt with contractually. At the same time, much the same stakeholders are likely to benefit, too: the production of new economic knowledge "inevitably involves spillovers to others besides the shareholders such as the employees and the customers/suppliers" (Arrow, 1962, p.10). Where stakeholder spill-overs are high, much depends on the relationship among the parties being co-operative and close stakeholder inclusion.

3.3 What shapes the relationships of firms in a developing economy? How do their relationships affect their learning?

Macdonald (1998) (as likewise(von Hippel, 1988; , 2005) has shown that successful innovation typically requires important interchange of information among firms. Such interchange flourishes where the relevant relationships are informal and based mainly on personal contacts (Macdonald \& Assimakopoulos, 2003). Moreover, the competition of the market encourages much more information exchange than collaboration, 


\section{A. Tylecote, J. Cai and J. Liu}

even collaboration intended specifically to facilitate innovation (Piekkari \& Macdonald, 2005). But the information exchange referred to is that among competing firms. What of that between seller and buyer of machinery or components? There is an underlying formal relationship here, the contract of sale, on which a richer skein of informal relationships may be built. What determines the richness, the closeness of these relationships? The development and maintenance of close inter-firm relationships are opaque and slow pay-off activities in the sense explained above, and thus much affected by the degree of engagement of shareholders or others in control of the firm. For Britain, Cantista and Tylecote (Liu \& Tylecote, 2008forthcoming) found that there was a clear connection between the ownership/corporate governance status of firms and their behaviour within relationships with industrial customers and suppliers. Those which were public listed companies (PLCs) had less close relationships than those which were not. The essential difference, in the British case, was that the PLCs had shareholders (mostly British financial institutions, through pension fund and mutual fund portfolios) that had power over management (they might sell to a take-over bidder or even intervene to get rid of them directly), but did not engage with it: they did not spend time to understand in depth what its strategy and performance were. 
Why is Mainland China Rising in Some Sectors and Failing in Others?

Firms in developing countries face a particular choice, or spectrum of choices, with respect to 'learning relationships' with other firms. The most direct, quick and certain way of 'acquiring' more advanced technology than they currently have, is to engage in highly unequal relationships with foreign, advanced firms, in which the latter supply - sell - 'bundles' or 'packages' of technology in large discrete transactions. 'Acquire': they are able to produce more advanced products with more advanced processes, so that one can say they have improved their static capabilities, but the learning process is at best passive - they do not thus acquire dynamic capability, or (to use Gu and Lundvall's phrase (2006)) 'indigenous innovation capability'. Such deals are also expensive. At the other end of the spectrum of choice, they can depend on rather equal relationships with other domestically-owned firms. These need to carry a relatively heavy weight of trust, with both firms learning together and depending on the other's support. (This is the classic pattern within Japanese kigyo shudan, or horizontal industrial groups.) They will also need to depend rather heavily on relationships with their lower-level employees, whose cooperation and initiative will be required much more in this situation than where processes and products are being 'handed to them on a plate'. The latter relationships, and the technological learning that take place within them, are far more opaque than the former, 'bundling' relationships (Liu \& 


\section{A. Tylecote, J. Cai and J. Liu}

Tylecote, 2008forthcoming). They are therefore much less likely to be encouraged by a governance system with low engagement.

\section{The Chinese national system of innovation, and its external tilt}

\subsection{Corporate governance and finance in China}

In China, the corporate governance issue started to arouse attention in the late 1980s and the concept became more familiar to China in the late 1990s (Fei, 2004). The discussion related mainly to state-owned enterprises. In order to revive a struggling public sector accounting for over $70 \%$ of the nation's economy in the late 1970s, Chinese authorities aimed at restructuring state-owned enterprises by establishing a 'Modern Enterprise System' (Xiandai Qiye Zhidu), in which corporate governance was the main focus. In 1984 SOEs became shareholding enterprises. In 1990 the Shanghai Stock Exchange, closed since 1949, was reopened; the following year the Shenzhen Stock Exchange was opened. As of end 2003 there were 1287 enterprises listed on the exchanges, of which 940 were SOEs (Hua et al., 2006). In 1993 a Company Law was passed, which set up a two-tier board structure and replaced the laosanhui, the 'three old organisations' (Communist Party committee, labour union and employees representative meeting) by the xinsanhui, the 'three new organisations' (shareholders meetings, supervisory board, executive committee). Accounting Standards for Business Enterprises were issued in the same 
Why is Mainland China Rising in Some Sectors and Failing in Others?

year (Hua et al., 2006). A code of corporate governance and guidelines were issued for listed companies (CSRC, 2001). However, despite the effort to reform and enforce formal arrangements, some fundamental flaws in the governance of Chinese firms, especially of SOEs, remained (Zhang, 1998), and these flaws have had an impact on firms' technological development. (What follows refers to the situation up to the further reforms of 2003. The latter are discussed later.)

Until 2003 the control and supervision of each SOE was almost entirely in the hands of the appropriate ministry. This gave ministry officials every opportunity to interfere with firms' operational decisions. Nonetheless, even more important than this interference was the way managers were appointed and assessed. The top managers of Chinese SOEs were selected by government "bureaucrats" rather than "capitalists"(Chen \& Huang, 2001; Gronewegen, 2004), According to a survey conducted in 2000 by the Chinese Entrepreneurs Survey System, from 1979 to 2000 around 76 $\%$ to $80 \%$ of chief executives of SOEs were appointed by government authorities (http://www.cess.gov.cn/dcyj/diaocha.htm\#), and traditionally the selection was largely based on the candidate's political merits. These managers were sent to a firm with a view to stay for a limited period of time (typically five years), and looked to be moved to a higher position, in a larger firm or a ministry. Their career paths were essentially that of 


\section{A. Tylecote, J. Cai and J. Liu}

officials. The short time horizon does not encourage managers to think long; on the contrary, they need to make a quick and good impression on senior officials (Zhang, 1998) - themselves subject to regular rotation and unlikely to 'engage' closely with the firm. Thus one of the key effects of the governance flaws of Chinese SOEs is managerial short-termism (Tylecote \& Cai, 2004). The incentive for commitment to real technological learning, and the development of indigenous innovation capability', is therefore lacking - the process being slow in pay-off, high in uncertainty, and opaque - for incumbent managers, it is unlikely to bring them a pay-rise or promotion. (For recent developments see Section 6.)

Administratively appointed managers have little time for employee inclusion and inter-firm relationship building. The continuing powerful state hierarchy and the unique blend of "capitalism with Chinese characteristics" means that although many firms have gone through the process of 'marketisation', the state's major stake remains in most, especially large-scale SOEs. Firms in China still have certain idiosyncratic political aspects (this also applies to POEs). According to an interview with Chief Party Secretary (also Chief Operations Officer as well as board member) of an $\mathrm{SOE}^{2}$, he needed to report regularly to the city's Party Organisational Committee (Zuzhi Weiyuanhui) about details of the firm's 
Why is Mainland China Rising in Some Sectors and Failing in Others?

"state of political stability, the programme and progress of moral and political education", etc. Top managers' remunerations and career perspective are associated with such political performance. On the other hand, personal guanxi with bureaucrats is also important and needs cultivation/ maintenance - therefore managers have limited time or incentive to build stakeholder relationships.

Privately-owned firms (POEs) in China have had a very different situation. Being very recently established (since 1980), the CEO is usually the majority, often sole, shareholder. In consequence they have fully-engaged shareholders well able to cope with opacity; there is no significant information asymmetry in corporate governance. Their most obvious problem has been poor access to finance (as to some other resources, such as land and licenses) (Cai \& Tylecote, 2005). Less obviously, private firms' managers/owners also need to invest time and money in building guanxi with officials. It is clear that relationships among Chinese firms and between firms and government are subject to unusual pressures arising from the nature of the political structure and of the process of transition (Krug \& Hendrischke, 2007). The insecure nature of property rights means that private firms have depended heavily on connections with powerful officials to protect what would elsewhere be protected by the law.

\footnotetext{
${ }^{2}$ Interview, face-to-face, May 2006.
} 


\section{A. Tylecote, J. Cai and J. Liu}

Likewise they cannot rely simply on the market to give them access to key resources such as finance: connections are needed for that too, either with officials to give them access to cheap state-controlled finance (banks, stock market) or with other private firms and rich individuals to get access informally to private finance.

\section{Finance in China}

State-owned banks dominate the Chinese financial system and as of 2000 held more than $60 \%$ of the country's banking assets (Saussure et al., 2001) - much more than that, ten years previously. They prefer to lend to (central) state-owned firms, and among the rest they show particular aversion to private enterprise. Even at the end of 2001, the private sector received less than $1 \%$ of all loans granted by the state banking system (Tsai, 2002). For SOEs, bank loans are or used to be very cheap - in the early 90 s, typically 1\% interest from a state-owned bank (Oi, 1995); in early 2004 interest rates were $4 \%-7 \%$ on loans, but as little as $2 \%$ on discounted bills (www.bank-of-china.com).

Outside the state banking system many shareholding commercial banks and city or regional private banks have recently appeared in the financial system. Even these, however, appear to discriminate against the private sector: the new banks respond to guanxi like everybody else - rationally 
Why is Mainland China Rising in Some Sectors and Failing in Others?

enough. Private firms are more likely to be hit by bureaucratic actions or inactions beyond their control, and if in trouble for any reason will not be bailed out by the state. They are thus worse risks. So most of the new banks prefer to lend money to those large private firms with good credit, or provide loans only against collateral (Langlois, 2001; Liu, 2002).

As another actor in the Chinese financial system, the Chinese stock market (mainland) has developed very quickly since it was established in 1992. But it is hardly used by the private sector as a channel to raise funds. The state decides the quotas of listing and selects the firms which may list on the stock market (Langlois, 2001). If a private firm wants to be listed in the stock market one pragmatic way is to buy an already listed enterprise, which not only incurs high cost but is also subject to regulations (Bruton \& Ahlstrom, 2003).

Venture capital financing on a limited scale has been taking place in China in recent years. By the end of 1999, China had 92 venture capital companies with 7.2 billion yuan (US\$870 million) of funds (People's Daily, 2002). More than $80 \%$ of the venture capital funds in China were provided by the government, with the remaining less than $20 \%$ from foreign and private investors (Lo, 2000; ). A number of factors deter 


\section{A. Tylecote, J. Cai and J. Liu}

venture funds from flowing into start-up private firms. Firms seeking funds are required to show at least three years of financial accounts - and accounts in China are unreliable anyway. To evaluate a firm a venture investor needs in particular to know the sort of guanxi which are possessed by the firm and by its managers as individuals: as we have seen, these contacts constitute valuable assets in Chinese business (Bruton \& Ahlstrom, 2003).

\subsection{The relationships of Chinese firms, and their 'external tilt'.}

One notable feature of the Chinese NSI, before the reforms, was the dependence of the system on the R\&D institutes ( $\mathrm{Gu}, 2003 ; \mathrm{Gu} \&$ Lundvall, 2006). Any technology brought in from abroad came to them, in the form of technology licensing or sample machine procurement: they then 'fed' the enterprises, particularly the capital goods producers, whatever innovation or technological change took place. In the reform process of the 1980s and 1990s the government required the institutes to put their relationship with the producing enterprises on a market basis, selling their services. The selling of knowledge is a precarious business, as economic theory has demonstrated, and the preference of the institutes was to become capital-goods producing enterprises (NTEs, new technology enterprises) themselves $(\mathrm{Gu}, 2003)$, which generated some notably successful firms (e.g. Datang, Lenovo). By 2005 the proportion of 
Why is Mainland China Rising in Some Sectors and Failing in Others?

business-funded R\&D performed by research institutes had fallen to $1.1 \%$, below that performed by universities $(5.4 \%)$; more than $80 \%$ of $\mathrm{R} \& \mathrm{D}$ performed by research institutes was government-funded, whereas only $54.9 \%$ of that performed by universities was (www.sts.org.cn/sjk1/kjtjdt/data2006, Table 1-2).

So Chinese businesses do not now choose to have much of their R\&D performed externally. But this does not mean that they are looking to improve their technological capability 'indigenously' - as we can infer from their low R\&D intensity. They are still sourcing new processes and products externally, but now the main source is external to the country: their preference is typically to get new technology in a 'bundle' or 'package' from a leading foreign firm (Liu \& Tylecote, 2008). If innovation expenditure is broken down by class of innovative activity, the costs of acquisition for embodied technology, such as machines and production equipment, account for about $58 \%$ of the total innovation expenditures, compared with $17 \%$ internal $\mathrm{R} \& \mathrm{D}, 5 \%$ external $\mathrm{R} \& \mathrm{D}, 3 \%$ marketing of new product, $2 \%$ training cost and $15 \%$ engineering and manufacturing start-up (Guan, 2000). This has applied particularly to state-owned firms, which have good access to finance and other resources - most particularly to the 'insider' firms (Lu \& Feng, 2004) of the 'national team' (Nolan, 2001) which have had the best access. 


\section{A. Tylecote, J. Cai and J. Liu}

Let us now connect Chinese firms' approach to learning within relationships to the arguments above. The 'acquisition' of technology within a 'bundle', in a discrete transaction, minimizes opacity and reduces time to pay-off, thus representing an optimal strategy given typical SOE corporate governance. The reduction in opacity relates not only to the processes within the firm, but also to the relationship-building. Dependence on close and co-operative relationships with related domestic firms, and with lower-level employees, would make the process of technology acquisition less easy for monitoring officials to understand. At the same time, the time spent on cultivating relationships with officials leaves less time for cultivating what could be called 'constructive' relationships. This will apply particularly to relationships between SOEs and private firms, since the career paths of private sector managers have been unlikely to cross with those of SOE managers. Finally, we must also refer to Macdonald's finding that information interchange among rivals was stimulated by competition. This points to the weakness identified by Lu and Feng (2004): the 'featherbedding' of the 'insider' firms, protected from competition by government control of market access.

\section{The pattern of success in 'indigenous innovation'.}

There is evidence that poor corporate governance (broadly defined) has 
Why is Mainland China Rising in Some Sectors and Failing in Others?

been a major factor in inhibiting technological development in Chinese state-owned firms, while poor access to finance has had a similar inhibiting effect in privately-owned firms (Tylecote \& Cai, 2004; Cai \& Tylecote, 2005; Cai \& Tylecote, 2006; Liu \& Tylecote, 2006). (Poor access to finance also discourages investment in slow pay-off activities.)

In this section we review the pattern of success among and within sectors, and show that it is consistent with our arguments about the characteristics of the Chinese NSI and the specific nature of corporate governance, finance and inter-firm relationships. We shall begin by considering the exceptional successes: why telecoms and DVPs have succeeded and the motor industry is succeeding.

\subsection{The small exception.}

The digital video player industry has an obvious key feature: its products are not sold to industrial customers. There are thus no inter-firm relationships with customers that need to be developed. The DVP manufacturers may need good IFRs with component suppliers - and indeed since these are 'assembled' products, they probably will need them - but at least they are in control: the component suppliers are likely to be smaller than them and will dance to their tune. (The exception will be foreign suppliers of high-technology components.) Lu's account (2005) of 


\section{A. Tylecote, J. Cai and J. Liu}

the development of the DVP industry shows a Darwinian process of natural selection at work in which private firms with little capital but the right strategies came to the forefront. (To be exact, this process began only after a state-owned firm had made a crucial technological breakthrough which it proved unable to exploit commercially - bearing out the vital role of SOEs.) Government policy and favour to 'insider' firms was irrelevant because the government did not really have a policy for these sectors.

There is a connection here with ownership and corporate governance. The successful 'outsider' firms in all sectors all seem to have one thing in common: they are not majority-owned by the central government. Most common are minority-state-owned firms like TCL and (Ningbo) Bird where the original state owner was a city or town in one of the go-ahead regions, and where the managers were allowed to build up a large shareholding (Cai \& Tylecote, 2005). From a 'Darwinian' point of view, this is significant simply because there are many cities and towns in China, and therefore many potential owners of firms, some of which may be properly managed (and governed), and will rise to the top in open market competition. But it is also significant because, as Cai and Tylecote (2005; , 2006) argue, the minority SOE form of ownership, with management shareholding, does produce a combination of engaged shareholders (the managers, at least) and reasonably good access to finance and other 
Why is Mainland China Rising in Some Sectors and Failing in Others?

resources (through the role of the local government).

\subsection{Telecommunications}

Telecommunications equipment is an industry which is exceptional within the broader area of 'electronics/ICT' in at least two ways. The first is its success - to be precise, the success of mainland Chinese firms - in international competition. See

Figure 1, Figure 2 and Table 1. The rise of Huawei, the largest Chinese telecoms equipment manufacturer, has been remarkable. In less than 10 years, Huawei has set up 20 branches and 100 offices outside China, selling to over 100 countries and regions with over 1 billion customers. It has 12 foreign-based research centres and 28 regional training centres. In 2007 , over $72 \%$ of its sales revenue was generated from the overseas market. In December 2005, Huawei, together with three other multinationals: Ciena, Lucent and Siemens, became supplier of British Telecom's $\$ 17.4$ billion 21 st Century Network $(21 \mathrm{CN})$, which “... has been one of the largest single procurement programmes ever undertaken in the communications industry worldwide" (BT Group, 9/12/05,http://www.btplc.com/21CN/WhatisBTsaying/Keymilestones/Key milestones.htm()). ZTE, the second-largest telecoms equipment manufacturer, is following the same trajectory, approximately two years behind. Its overseas expansion started off with a US\$95 million turnkey 
A. Tylecote, J. Cai and J. Liu

contract in Pakistan in 1998, followed by a series of trials in Islamabad. In 2003 it became the largest CDMA system provider in BSNL - India's largest telecoms service company, and constructed Africa's largest CDMA WLL network in Algeria. Equally evident is ZTE's ever growing technological competence. After its first R\&D centre opened in the USA in 1998(designated for developing CDMA technologies) it successfully claimed a few world's records: world's first dual frequency hand set in 1999, first CDMA handset with detachable SIM card in 2000 and first CDMA 2000-based digital Trunking architecture in 2004. (ZTE website:http://wwwen.zte.com.cn/main/about/Intro/overall/index.shtml?ca talogId=12070).

From 2004 to 2006, the company entered partnerships with the top 50 global GSM/WCDMA systems equipment operators, as well as six of the top ten WCDMA telecom vendors in terms of terminals. In 2006, it secured 10 WCDMA deployment contracts in Western Europe, South America and Asia Pacific. In 2007 its total revenue was \$4.6bn, of which $57.8 \%$ was generated from overseas markets, and its sales growth in Europe and North America was 155\%. (ZTE website: (http://wwwen.zte.com.cn/main/News\%20Events/Whats\%20New/200804 0260720.shtml). 'It is believed that the recent merger and acquisition deals between Ericsson and Marconi, Alcatel and Lucent, and Nokia and 
Why is Mainland China Rising in Some Sectors and Failing in Others?

Siemens were at least partly designed to "fight off competition from Huawei and ZTE".' (Cheng Li, 2007, p.2). We are not aware of any other part of the ICT industries in which the leading players are (or seem to be) afraid of their Chinese rivals.

The second exceptional feature is that Chinese firms in telecoms equipment never had the option of the technological dependence implied in the 'bundling' strategy. Advanced technologies were simply not available on the international market because the US government treated the sector as strategic. It was therefore necessary for Chinese firms to develop their own technology, starting from the relatively backward technologies which were available (Cai \& Tylecote, 2006). It can be, and has been, argued that it was this 'forced' independent development which made Chinese telecoms more successful than (for example) television manufacture (Gao et al., 2007).

But it is also significant that the most successful Chinese firms - Huawei, ZTE - are, again, 'outsider' firms, in spite of the resources that were poured into, and favour shown to, other, 'insider' firms. Huawei is a secretive firm, and its ownership structure is not altogether clear, but it is officially described as a private firm, and it has at least one feature characteristic of private firms: its founding CEO, Ren Zhengfei is still its 


\section{A. Tylecote, J. Cai and J. Liu}

CEO. And although Ren was an entrepreneur with good connections, the limits of his connections were shown by the way Huawei was obliged to develop over many years depending heavily on reverse engineering (rather than conventional $R \& D$, which it could not originally afford much of with a start-up capital of a mere $\$ 3000$ in 1988), and on relationships cultivated slowly and with much effort, with relatively small, mainly rural local governments which needed telecoms equipment and could not pay much for it. An engaged shareholder - in Huawei's case, the CEO himself - was willing and able to support the slow, low-visibility development of real endogenous technological capability. ZTE was set up in 1985. Unlike Huawei, it was a state-owned enterprise, but a quite untypical one. It was initially called Zhongxing Semiconductor Co. Ltd, and it was set up by three founding SOEs, headed by No.691 Factory, which was under the former Ministry of Aerospace Industry (the others were Changcheng Industrial Co. Ltd (Shenzhen Office) and Yunxing Electronic Trading Co., Ltd.). Conflicts of interests among the shareholders led some of the senior management, led by Hou Meigui, the founding CEO, to set up a company named Zhongxing-Weixian Telecommunication Equipment Co., Ltd (ZXWXT), in December 1992, which four months later took over the management of the newly-renamed Zhongxing Telecommunication Equipment Co. Ltd., by agreement with its now two SOE shareholders, No.691 Factory and Guangyu Industrial Co. Ltd. (Shenzhen). "The three 
Why is Mainland China Rising in Some Sectors and Failing in Others?

sponsors signed a contract that ZXWXT take charge of the business with their assets as mortgage. If they achieve all the goals, they could earn more; otherwise, they would pay for the losses." (internal memorandum.) ZXWXT had only a small minority of the shares, but held effective control, under the not-uncommon rule of 'State-owned but empower others to operate.' ZTE Corporation was listed in Shenzhen Stock Exchange in 1997 and Hong Kong in 2004. Its state shares dropped below 50\% in 2003. One clear sign of the exceptional nature of corporate governance in ZTE (for an SOE) is the attachment of top management to the firm. Hou Meigui, the founder of the firm, is still in control, albeit as chairman rather than CEO, after more than twenty years. Such permanence in authority can be found, strikingly, in five of the largest six Chinese electronics/IT firms Legend, Haier, BOE, Huawei and Midea ${ }^{3}$ - whose founders were still in charge in 2006 after an average of 22 years. (Cheng Li, 2006). Opaque, slow-pay-off strategies would have been much more attractive to them than to the typical, short-stay official CEO.

\section{Figure 1: Local products vs. imported products in the telecom switch} market in China (1982-2000)

\footnotetext{
${ }^{3}$ Haier and Midea were originally, and are still largely, home appliance manufacturers, which have moved into electronics rather recently.
} 
A. Tylecote, J. Cai and J. Liu

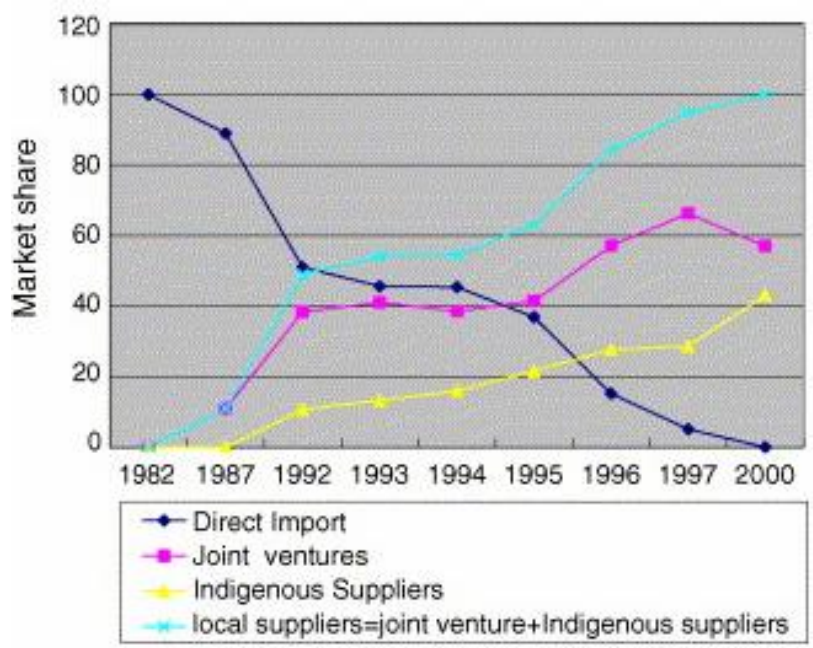

Souce: (Mu \& Lee, 2005)

Table 1 Stored Programme Control Exchange (SPC) annual market share by three groups in China (1982 -2000)

\begin{tabular}{llllll}
\hline \hline & 1982 & 1987 & 1992 & 1997 & 2000 \\
\hline Direct import (\%) & 100 & 89 & 54 & 5 & 0 \\
Joint venture (\%) & 0 & 11 & 36 & 63 & 57 \\
Domestic supplies (\%) & 0 & 0 & 10 & 32 & 43 \\
\hline \hline
\end{tabular}

Source: (Tan, 2002)

Figure 2 Value of sales contract of Huawei: 2002-2007 (100 million US dollars) 
Why is Mainland China Rising in Some Sectors and Failing in Others?

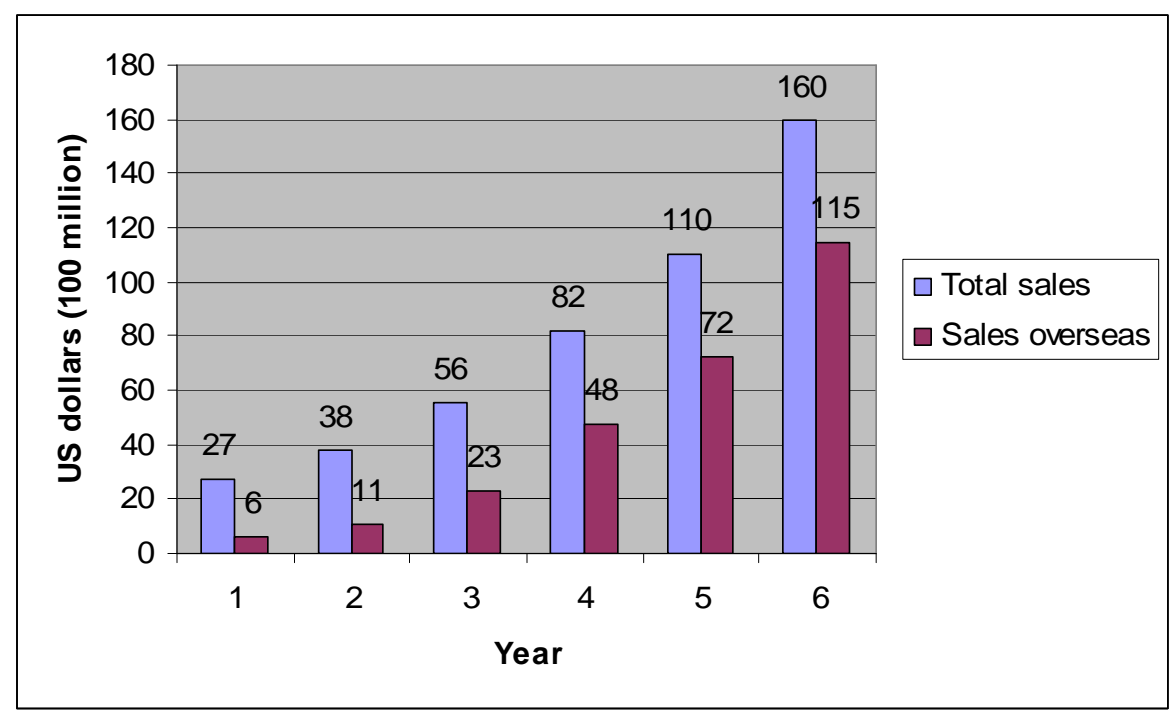

Source: Huawei website: http://www.huawei.com/about/AboutIndex.do (Accessed 08, June 2008) 


\subsection{The motor industry}

The motor industry resembles telecommunications in respect of the strategic importance that the government gave to it, with the selection of 'insider' firms for favour and support. It was quite different, however, in its freedom to buy technology from abroad, which the Big Three firms (Shanghai Automotive, Dongfeng, First Automobile Works) did through joint ventures with major multinationals. Until the last decade the privileged position they enjoyed gave them industry dominance, and the industry was one which showed all the bad effects both of 'featherbedding', profitability without effort or real competition, and of the classic mal-governance of state-owned firms. Over the last ten years the industry has been transformed, with the gradual introduction of increasing competition from abroad, and the sudden introduction of increased domestic competition from relatively small new entrants such as Chery and Geely. Figure 3 and Figure 4 show how 'domestic brands' made by domestically-owned firms outside joint ventures - have held their position in the domestic market in spite of the increased openness to foreign competition (from wholly-owned subsidiaries as well as imports) following WTO entry in 2001-5. Chery is the first Chinese domestic passenger car brand to have sold 300,000 units in a year. In the same year one of its models ranked No. 1 in the best-seller list on the Chinese market; 
Why is Mainland China Rising in Some Sectors and Failing in Others?

and Chery's domestic market share growth also surpassed all of its competitors - foreign or domestic. Exports of these domestic brands have also begun to climb rapidly. Chery has become the biggest car exporter based in China, with highest total sales growth in 2006. According to the statistics of International Organization of Motor Vehicle Manufacturers, in 2006, Chery has become the world's fastest growing car manufacturer at the rate of $65.62 \%$ (http://oica.net/wp-content/uploads/2007/07/chery.pdf).

What we have shown (Liu \& Tylecote, 2008) is that, again, success has come from better corporate governance. The main change in corporate governance has been that new entrants have better CG. The most successful new entrants, Chery and Geely, are respectively an SOE owned by Wuhu (a city in Anhui province) and the Anhui provincial government, and a private firm built up originally to produce vehicle parts. Chery however does not appear to have had significant managerial shareholding, and nor did Guizhou Tyre (GTC), a firm which has also been notably successful in developing technological capability, albeit over a much longer period. What both appear to have had is managerial 'ownership' in a much more general and slightly metaphorical sense: the management was assured by the formal owners, the local/provincial government, that they would support them over a long period, and that if they were successful over that period they would be suitably rewarded. In the 


\section{A. Tylecote, J. Cai and J. Liu}

Chinese context, given the insecurity of private property to which we referred in section 4 , such a secure relationship with power is as good as a shareholding. Indeed in some ways it is better. A private entrepreneur, at least until very recently, would have some inclination to avoid focusing his energies and capital on one area, because of the threat from official caprice. Safer to 'hedge his bets' by investing in several areas. (This indeed applies to entrepreneurs anywhere, because of market and technological uncertainties; the Chinese situation is simply more uncertain.) He may indeed choose to move much of his capital out of the country, to make it as safe as possible. The managers in Chery and Guizhou Tyre have no alternative to focusing their energies.

Another improvement in corporate governance seems to have taken place in the incumbent firms. SAIC, at least, has moved from being run by a succession of CEOs who were recruited as officials rather than industry specialists and moved on after 5 years or so, in the classic manner - to a CEO (Hu Maoyuan) who is an industry specialist and has been in post already for considerably longer (Liu and Tylecote, 2008). 
Why is Mainland China Rising in Some Sectors and Failing in Others?

Figure 3 Market shares of various brands, 2007-2008

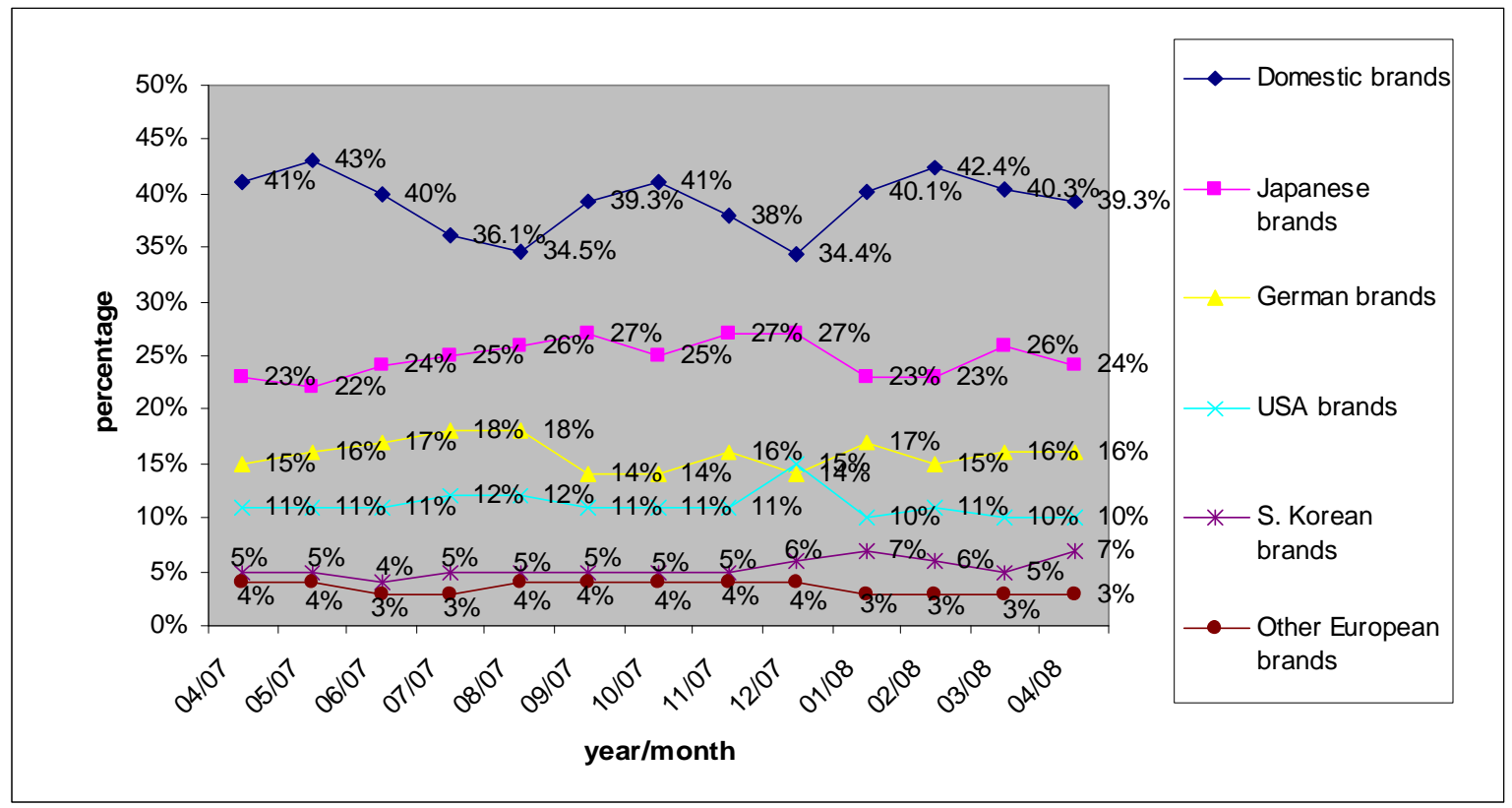

Source: Beijing Lange Steel Information Research Centre.

URL: $\quad$ http://www.lgmi.com/shanghailg/info/detailnewsb.asp?infono=514634 (accessed in June 2008) 
Figure 4 Market shares of domestic brands in passenger car segments, 2007-2008

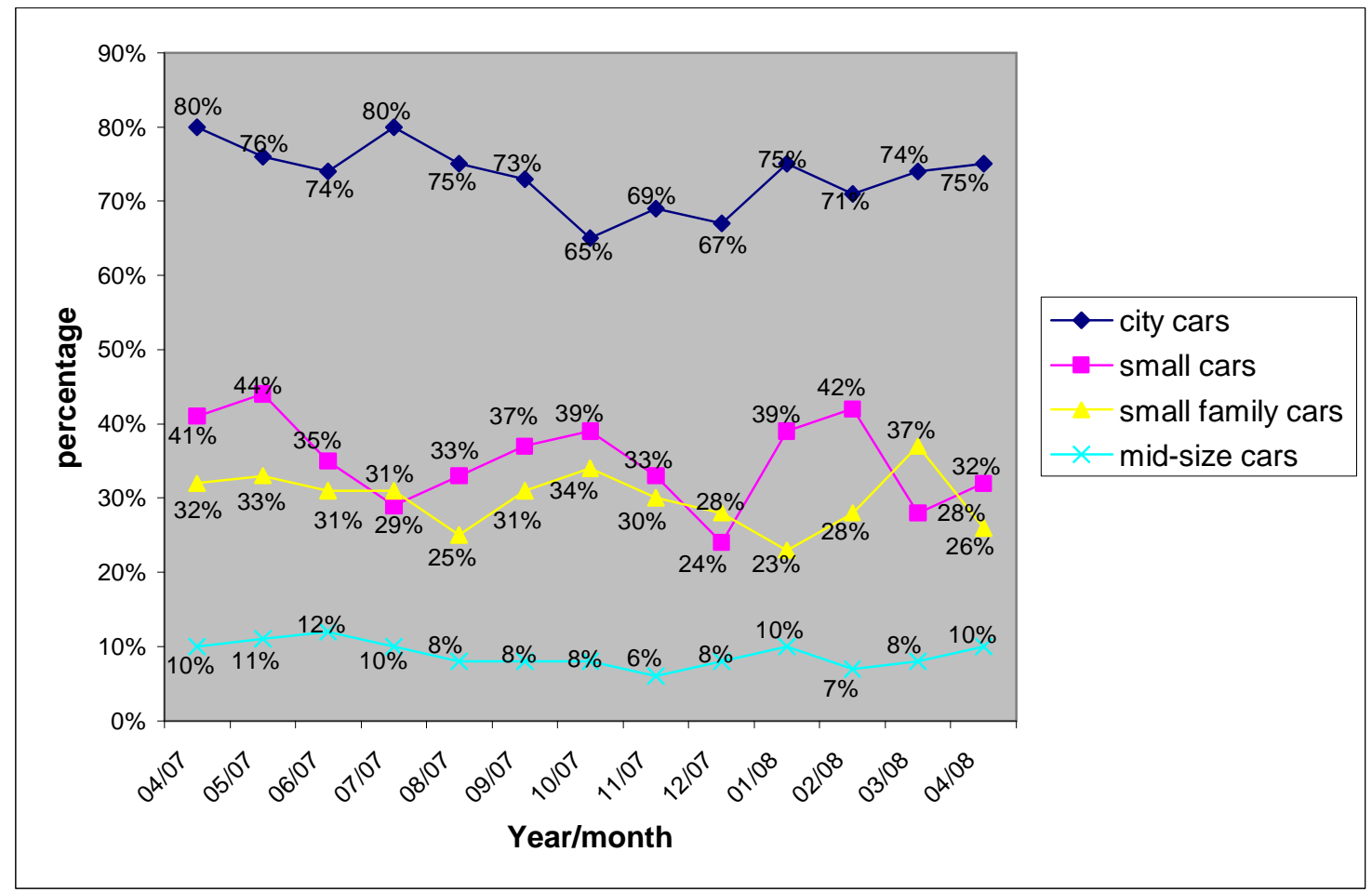

Source: Beijing Lange Steel Information Research Centre.

URL: $\quad$ http://www.lgmi.com/shanghailg/info/detailnewsb.asp?infono=514634 (accessed in June 2008)

\subsection{Inferences from the successes}

We have seen from the cases described in this section that Chinese firms which have been successful in building up dynamic technological 
Why is Mainland China Rising in Some Sectors and Failing in Others?

capability (or 'indigenous innovation') have had one common, and unusual feature - managerial continuity - even though they covered the full spectrum of ownership types, from full state ownership to full private ownership. It appears that this continuity made them more disposed than the average SOE to opaque, slow-pay-off activities and expenditures.

The relation between the corporate governance of individual successful firms, and the characteristics of the sectors in which they operated, is more complex. The digital video player industry was one in which (once the initial groundwork was laid by an SOE) entrepreneurial private firms could thrive: it was new, it did not require large scale, it dealt directly with the mass consumer market. Telecoms equipment was a sector in which the 'easy' (though expensive) option of buying a 'bundle' of advanced technology from a multinational (in a joint venture or separately) was, because of the military sensitivity of the sector, not available. This meant that the SOEs with more typical governance were unable to use their preferred method of getting a strong position in the market. This left the market relatively open to those firms which, due to their 'long-termist' governance, were prepared to do it the hard (and ultimately more productive) way. The motor industry was quite different again - the SOEs with typical governance, the Big Three, had an excellent means open to them of getting a strong market position - joint ventures with leading foreign firms. What they proved unable to do was to advance from there to real 'indigenous innovation' capability. Given the size, rate of growth and profitability of the Chinese car market, this left an opportunity open to 


\section{A. Tylecote, J. Cai and J. Liu}

new firms, whether SOE or private, which (due to their 'long-termist' governance) were prepared to follow 'unbundled' strategies with opaque technological activities. Entering at the bottom end of the market (where the Chinese consumer cared most about cheapness and least about fashionable foreign brands) they were able to build up technological capability before moving up-market to challenge the foreign brands (manufactured in joint ventures involving the Big Three). The highlycompetitive situation thus created has stimulated technological learning throughout the industry. Meanwhile, the corporate governance of the Big Three has improved, partly through the establishment of SASAC (see next section).

\section{The reform of SOE corporate governance, and its dangers}

The state-owned enterprises which once dominated the economy have changed in two directions. First, many, particularly of the smaller SOEs, have been privatised, wholly or partly. This may in many cases have involved an unacceptable transfer of wealth from government to private hands (Hua et al., 2006), but from a corporate governance point of view it must be generally an improvement. Second, those which remain, particularly those under central government ownership, are being governed in an increasingly conventional Anglo-American manner, with their performance being evaluated by normal Western financial accounting 
Why is Mainland China Rising in Some Sectors and Failing in Others?

measures, and with the stress on their responsibility to shareholders (including the state). 'Chinese authorities generally consider the AngloAmerican legal and regulatory systems to be the prototype for their “modern" institutional and enterprise reforms.' The State-owned Assets Supervision and Administration Commission of the State Council is a special commission, directly under the State Council. It is responsible for controlling China's 189 large central government owned firms, including appointing top executives and approving any mergers or sales of stock or assets, as well as drafting laws related to state-owned enterprises. Since its foundation in 2003, SASAC has been trying hard to formulate systematic performance measurement for its SOEs (see Table 2 for the details of evaluation method for central enterprises by SASAC). Compared to its predecessors (industrial ministries at the central level and bureaus at the local level), SASAC has more expertise in external supervision over the firms' operational activities. We can expect that SASAC officials, given that their job is mainly about supervising firms, would be able and willing to engage more closely and intelligently. Meanwhile, it attempts to include innovation performance in the comprehensive assessment system. To this extent, there should be a positive impact on firms' technological strategy.

There are still problems associated with the current arrangement. First of all, the short-termism issue is not fully addressed. According to the recent 


\section{A. Tylecote, J. Cai and J. Liu}

measures for assessing "persons in charge of central enterprises" (Chief Executives and Chief Operations Officers) (Shousheng Li, 2007), if within three years a firm fails to reach the target set by SASAC $(70 \%$ of which is composed of financial indicators, and $<5 \%$ based on innovation performance), the person in charge runs a risk of job loss. Such financial pressures can be highly positive in bringing a new emphasis on efficiency through the reduction of waste, and focus on what is commercially rewarding. The difficulty is that if a CEO has a relatively short time to make his or her mark on a firm, and that mark will be measured financially, slow pay-off investments in technological capability will be discouraged. Precisely that has been the situation in British plcs, with a clear damaging effect on their technological capability and (by now) on their growth in higher-technology areas (Tylecote \& Ramirez, 2006). In the United States, too, the ill-effects of such pressures have been noted (Porter, 1992; Lazonick \& O’Sullivan, 2000).

Happily Chinese SOE governance in practice continues to be extremely diverse, as Hua et al. show, distinguishing four types of SOE according to the strength or weakness of the new and old governance regimes, xinsanhui and laosanhui (supervisory and executive boards and shareholders' meetings; party committee, labour union and employees' meetings). Their 'hybrid' type, in which both new and old regimes are 
Why is Mainland China Rising in Some Sectors and Failing in Others?

strong, is of particular interest. The example they give had a minority state shareholding, minority shareholdings held by private institutions, and a substantial employee shareholding which in effect held the balance between state and private shares. This balance among shareholders helped to make the new governance regime a reality, because no one player held all the cards. It also played a key role in giving life to the old governance regime. Because the employees had both a direct interest in the profitability of the firm, and a share of power over its management, they participated actively in the laosanhui. They also (we would expect) worked harder individually. In terms of our framework of analysis, this firm has engaged shareholders (including its employees) well able to appreciate and support opaque and slow-pay-off activities; and it has stakeholder inclusion, at least as regards employees, thus making it easier to deal with spill-overs. It is striking that while this type can be regarded as peculiarly Chinese in the specific institutions involved, the outcome is not very different from the practice in many US firms, where employee inclusion is achieved, as here, largely through substantial employee shareholdings (Tylecote and Ramirez, 2006). 
Int. J., Vol. $x$, No. $x, x x x x$

Table 2 Portfolio of performance assessment in central enterprises by SASAC

\begin{tabular}{|c|c|c|c|c|c|c|c|}
\hline \multicolumn{6}{|c|}{ Financial Performance $\mathbf{( 7 0 \% )}$} & \multicolumn{2}{|c|}{$\begin{array}{c}\text { Managerial } \\
\text { Performance }(\mathbf{3 0 \%})\end{array}$} \\
\hline \multicolumn{2}{|c|}{$\begin{array}{c}\text { Content and Weight } \\
(\%)\end{array}$} & Basic indices & $\begin{array}{l}\text { Weight } \\
(\%)\end{array}$ & $\begin{array}{l}\text { Reference } \\
\text { indices }\end{array}$ & $\begin{array}{l}\text { Weight } \\
(\%)\end{array}$ & $\begin{array}{l}\text { Assessment } \\
\text { Item }\end{array}$ & $\begin{array}{l}\text { Weight } \\
(\%)\end{array}$ \\
\hline \multirow[b]{2}{*}{ Profitability } & \multirow[b]{2}{*}{34} & \multirow{2}{*}{$\begin{array}{l}\text { Net asset earning } \\
\text { ratio }\end{array}$} & 20 & \multirow{2}{*}{$\begin{array}{l}\text { Sales profit rate } \\
\text { the surplus cash } \\
\text { cover ratio } \\
\text { Profit/cost of } \\
\text { capital (EVA) } \\
\text { Rate of earnings } \\
\text { on equity }\end{array}$} & \multirow{2}{*}{$\begin{array}{l}10 \\
9 \\
8\end{array}$} & $\begin{array}{c}\text { Strategic } \\
\text { management }\end{array}$ & 18 \\
\hline & & & 14 & & & $\begin{array}{l}\text { Development } \\
\text { and innovation }\end{array}$ & 15 \\
\hline \multirow{2}{*}{$\begin{array}{l}\text { Asset } \\
\text { quality }\end{array}$} & \multirow[t]{2}{*}{22} & \multirow{2}{*}{$\begin{array}{c}\text { Total asset } \\
\text { turnover } \\
\text { Acct. receivable } \\
\text { turnover }\end{array}$} & \multirow[t]{2}{*}{10} & $\begin{array}{c}\text { NPL ratio } \\
\text { Current asset } \\
\text { turnover }\end{array}$ & $\begin{array}{l}9 \\
7\end{array}$ & $\begin{array}{l}\text { Operational } \\
\text { decisions }\end{array}$ & 16 \\
\hline & & & & Cash/asset ratio & 6 & $\begin{array}{c}\text { Risk } \\
\text { management }\end{array}$ & 13 \\
\hline \multirow[b]{2}{*}{ Debt risk } & \multirow[b]{2}{*}{22} & \multirow{2}{*}{$\begin{array}{l}\text { asset/liability } \\
\text { ratio } \\
\text { Paid interest/debt }\end{array}$} & 12 & \multirow{2}{*}{$\begin{array}{l}\text { Quick ratio } \\
\text { Cash ratio } \\
\text { Ratio of } \\
\text { liabilities to } \\
\text { interest } \\
\text { Contingent } \\
\text { liability ratio }\end{array}$} & \multirow{2}{*}{$\begin{array}{l}6 \\
6 \\
5\end{array}$} & $\begin{array}{c}\text { Basic } \\
\text { management }\end{array}$ & 14 \\
\hline & & & 10 & & & $\begin{array}{c}\text { Human } \\
\text { resource } \\
\text { management }\end{array}$ & 8 \\
\hline \multirow{2}{*}{$\begin{array}{l}\text { Operational } \\
\text { growth }\end{array}$} & \multirow{2}{*}{22} & \multirow{2}{*}{$\begin{array}{l}\text { Sales growth rate } \\
\text { Ratio of value } \\
\text { maintenance and } \\
\text { appreciation of } \\
\text { capital } \\
\end{array}$} & 12 & \multirow{2}{*}{$\begin{array}{l}\text { Sales profit } \\
\text { growth } \\
\text { Growth rate of } \\
\text { total asset } \\
\text { Technological } \\
\text { input ratio }\end{array}$} & \multirow[t]{2}{*}{$\begin{array}{l}10 \\
7\end{array}$} & $\begin{array}{l}\text { Influence in the } \\
\text { industry }\end{array}$ & 8 \\
\hline & & & 10 & & & $\begin{array}{l}\text { Contribution to } \\
\text { society }\end{array}$ & 8 \\
\hline
\end{tabular}

\section{Conclusion}

We have argued that the disappointing performance of Chinese firms in terms of technological capability arises largely from faults of corporate 
Why is Mainland China Rising in Some Sectors and Failing in Others?

governance and finance. Whereas the faults of the financial system have done most damage to privately-owned firms, and denied most of them the resources required to develop real technological capability in medium and high technology industries, it is the faults of corporate governance which are most apparent in state-owned enterprise, on which mainland China still relies to make an impact in medium and high technology sectors. This applies even to the deficiencies of inter-firm relationships, which have contributed greatly to weakness in certain important areas (notably, but not only, machinery). In some degree these faults can be remedied, and are being remedied, by 'normalisation' to a Western model. However the mechanical application of certain Western rules, such as financial accounting used as a means of corporate governance, is dangerous: the British example shows that to have real close, understanding relationships between shareholders (or their representatives) and managers is more valuable than simply to apply the 'correct' accounting formula. To evaluate firm performance by accounting criteria alone (or mainly) will be particularly dangerous now that the Chinese economy is heavily exposed to international competition (including that of multinational firms' subsidiaries within China): even more than ever, the development of real technological capability is likely to reduce profits before it increases them. Happily there are elements within the corporate governance systems of many Chinese SOEs which tend to confer the engagement and inclusion 


\section{A. Tylecote, J. Cai and J. Liu}

which we have argued is necessary. They have contributed to the sectoral successes we have described. It will be necessary to foster them. 
Why is Mainland China Rising in Some Sectors and Failing in Others?

\section{References}

1. Arrow, K. (1962) Economics of welfare and the allocation of resources for invention. National Bureau of Economic Research, The Rate and Direction of Inventive Activity. Princeton, NJ: Princeton Univ. Press.

2. Bruton, G. D., \& Ahlstrom, D. (2003) 'An institutional view of China's venture capital industry: Explaining the differences between China and the West'. Journal of Business Venturing, 18(2): 233-259.

3. Cai, J., \& Tylecote, A. (2005) 'A healthy hybrid: The technological dynamism of minority-state-owned firms in China'. Technology Analysis and Strategic Management, 17: 257-277.

4. Cai, J., \& Tylecote, A. (2006) Corporate governance and technological dynamism of Chinese firms in mobile telecommunications: a quantitative study IAMOT 2006 International Conference. Beijing.

5. Chen, J., \& Huang, Q. (2001) 'Comparison of Governance Structures of Chinese Enterprises with Different Types of Ownership'. China \& World Economy, 9(6): 11-21.

6. Christensen, J. L. (1992) The role of finance in national systems of innovation. In B.-Å. Lundvall (Ed.), National systems of innovation: Towards a theory of innovation and interactive learning: 146-168. London: Printer.

7. CSRC. (2001) Code of Corporate Governance for Listed Companies in China. China Securities Regulatory Commission (Beijing) enacted jointly with the State Economic and Trade Commission (7 January).

8. Fei, Y. (2004) The Institutional Change in China after its Reform in 1979 - An Institutional Analysis with a Focus on Mergers and Acquisitions, Erasmus University, Rotterdam.

9. Gao, X., Zhang, P., \& Liu, X. (2007) 'Competing with MNEs: developing manufacturing capabilities or innovation capabilities'. The Journal of Technology Transfer, 32(1-2): 87-107.

10. Gronewegen. (2004) 'Who Should Control the Firm? Insights from New and Original Institutional Economics'. Journal of Economic Issues, 38(2): 353-362.

11. Gu, S. (2003) NIS Transformation and Recombination Learning in China. Globelics Conference. Rio de Janeiro.

12. Gu, S., \& Lundvall, B. (2006) 'China's innovation system and the move towards harmonious growth and endogenous innovation'. Innovation: Management, Policy \& Practice, 8(1-2): 1-26.

13. Guan, J. C. (2000) Industrial Innovation in China: A Comparative Study Based on Survey Data. Working Paper: Peking University.

14. Hua, J., Miesing, P., \& Li, M. (2006) 'An Empirical Taxonomy of SOE Governance in Transitional China'. Journal of Management Governance, 10: 401-433.

15. Jensen, M., \& Meckling, W. (1976) 'Theory of the Firm: Managerial Behaviour, Agency Costs and Ownership Structure'. Journal of Financial Economics, 3(4): 305-360.

16. Kavanagh, R. (2006) BT announces further 21st Century Network progress four major contracts signed. I.T. Vibe, 06, March 2006.

17. Krug, B., \& Hendrischke, H. (Eds.). 2007. The Chinese Economy in the 21st Century: Enterprise and Business Behaviour. Cheltenham: Elgar.

18. Langlois, J. D. J. (2001) 'The WTO and China's Financial System'. The China Quarterly(167): 610-629.

19. Lazonick, W., \& O'Sullivan, M. (2000) 'Maximizing shareholder value: a new 


\section{A. Tylecote, J. Cai and J. Liu}

ideology for corporate governance'. Economy and Society, 29(1): 13-35.

20. Li, C. (2007) 'China's Telecom Industry on the Move: Domestic Competition, Global Ambition, and Leadership Transition'. China Leadership Monitor(19).

21. Li, S. (2007) How to Achieve Scientific Performance Assessment in the Central Enterprises: talk on the press conference. In C. State Assets Supervision and Administration Commission of the State Council (Ed.).

22. Liu, J., \& Tylecote, A. (2006) Corporate Governance and Technological Capability Development: Three Case Studies in the Chinese Auto Industry. CICALICS 2006 International Workshop. Chengdu, China.

23. Liu, J., \& Tylecote, A. (2008) 'Corporate Governance and Technological Capability Development: Three Case Studies in the Chinese Auto Industry'. Industry and Innovation.

24. Liu, Y. Q. (2002) 'Development of private entrepreneurship in China: process, problem and countermeasures'. URL: www.mansfieldfdn.org/programs/ program_pdfs/ent_china.pdf.

25. Lo, C. (2000) The Problem with Venture Capital in China. Virtual China Inc.

26. Lo, W. C. (2001) 'A Retrospect on China's Banking Reform'. Chinese Economy, 34(1): 15-28.

27. Lu, F. (2005) Learning by Innovating: Lessons from the Development of the Chinese Digital Video Player Industry. Memo. Beijing: Peking University.

28. Lu, F., \& Feng, K. (2004) Fazhan woguo zizhu zhishichanquan qichegongye de zhengce xuanze (In Chinese: The Policy Choice in Developing China's Proprietary Car Industry). Beijing: Beijing University Press.

29. Macdonald, S. (1998) Information for Innovation: Managing Change from an Information Perspective. Oxford: Oxford University Press.

30. Macdonald, S., \& Assimakopoulos, D. (2003) 'Personal Networks and IT Innovation within the Esprit Programme: Some Evidence from the UK'. Innovation: Management, Policy and Practice, 5: 15-28.

31. Mahmood, P. I., \& Singh, J. (2003) 'Technological Dynamism in Asia'. Research Policy, 32(6): 1031-1054.

32. $\mathrm{Mu}, \mathrm{Q} .$, \& Lee, K. (2005) 'Knowledge diffusion, market segmentation and technological catch-up: The case of the telecommunication industry in China'. Research Policy, 34(6): 759-783.

33. Nelson, R. R. (Ed.). 1993. National Systems of Innovation: A Comparative Study. Oxford: Oxford University Press.

34. Nolan, P. (1996) 'Large firms and industrial reform in former planned economies: The case of China'. Cambridge Journal of Economics, 20(1): 1-29.

35. Nolan, P. (2001) China and the global economy : national champions, industrial policy, and the big business revolution. New York: Palgrave.

36. Oi, J. C. (1995) 'The Role of the Local State in China's Transitional Economy'. The China Quaterly Special Issue: China's Transitional Economy(144): 11321149.

37. Pavitt, K. (1999) Technology, Management and Systems of Innovation. Cheltenham: Elgar.

38. Piekkari, R., \& Macdonald, S. (2005) 'Trusting the Ties that Bind'. $R \& D$ Management, 35(4): 441-453.

39. Porter, M. (1990) The Competitive Advantage of Nations. New York: Free Press.

40. Porter, M. (1992) 'Capital choices: changing the way America invests in industry'. Journal of Applied Corporate Finance, 5(2): 4-16.

41. Saussure, J. D., Frechette, H., \& Gryziak, B. (2001) Is the Banking System of the People's Republic of China ready to play with competitive WTO. Prepared for Chinese Challenge in the 21st Century. CEMS SP. 
Why is Mainland China Rising in Some Sectors and Failing in Others?

42. Schumpeter, J. (1911/1996) The Theory of Economic Development. New Brunswick: Transaction.

43. Schumpeter, J. (1942) Capitalism, Socialism and Democracy. New York: Harper.

44. Tan, Z. A. (2002) 'Product cycle theory and telecommunications industry-foreign direct investment, government policy, and indigenous manufacturing in China'. Telecommunications Policy, 26(1-2): 17-30.

45. Tsai, K. S. (2002) Back-Alley Banking: Private Entrepreneurs in China. Ithaca, N.Y: Cornell University Press.

46. Tylecote, A. (2007) 'The Role of Finance and Corporate Governance in National Systems of Innovation'. Organization Studies, 28(10): 1461-1481.

47. Tylecote, A., \& Cai, J. (2004) 'Chinas SOE Reform and Technological Change: A Corporate Governance Perspective'. Asian Business \& Management, 3: 57-84.

48. Tylecote, A., \& Ramirez, P. (2006) 'Corporate governance and innovation: The UK compared with the US and 'insider' economies'. Research Policy, 35(1): 160-180.

49. Tylecote, A., \& Visintin, F. (2008) Corporate Governance, Finance and the Technological Advantage of Nations. London: Routledge

50. Van Dijk, M., \& Wang, Q. (2005) The Development of A Software Cluster in Nanjing. European Congress on ITC. The Hague.

51. von Hippel, E. (1988) The sources of innovation. New York: Oxford University Press.

52. von Hippel, E. (2005) Democratizing Innovation. Cambridge MA: MIT Press.

53. Zhang, W. (1998) 'China's SOE Reform: A Corporate Governance Perspective'. Working Paper, School of Management, Peking University, No. 1998 E004. 